University of Louisville

ThinkIR: The University of Louisville's Institutional Repository

Electronic Theses and Dissertations

$1-1930$

\title{
Land laws of Kentucky.
}

Lillian Logan

University of Louisville

Follow this and additional works at: https://ir.library.louisville.edu/etd

Part of the Land Use Law Commons, and the United States History Commons

\section{Recommended Citation}

Logan, Lillian, "Land laws of Kentucky." (1930). Electronic Theses and Dissertations. Paper 850.

https://doi.org/10.18297/etd/850

This Master's Thesis is brought to you for free and open access by ThinkIR: The University of Louisville's Institutional Repository. It has been accepted for inclusion in Electronic Theses and Dissertations by an authorized administrator of ThinkIR: The University of Louisville's Institutional Repository. This title appears here courtesy of the author, who has retained all other copyrights. For more information, please contact thinkir@louisville.edu. 


\title{
UNIVERSITY OF LOUISVILIE
}

\section{IAND IAWS OF KBNTUCKY}

\author{
A Dissertation \\ Submitted to the Faculty of the \\ Graduate School \\ of the \\ University of Louisivilles \\ In partial fulfiliment of the \\ Requirements for the Degree of \\ Master of Arts
}

\section{DEPARTMENT OF HIST ORY}

By

IIILIAN IOGAN

1930 
TABLE OF CONTENTS

I. Introduction $\ldots \ldots \ldots \ldots \ldots \ldots \ldots \ldots \ldots$................. 1

II. The Kentucky Land office .............. Page 7

III. Old Virginia Land Grants ................ Page 19

IV. General Land Laws ................... Page 27

V. Laws Governing Later Acquisitions

The Cheroke

The Chlckasa Gountry .............. Page 52

VI. Special Land arants

The Surrendered Territory ........... Page 72

The Seminary Grants ............... Page 75

Grants for Manuf acturing ............ Page 79

Grants for Torns and for Counties..... Page 82

Grants for Relief of Individuals ..... Page 85

The Land Pollcy of Kentucky .......... Page 87

VII. Append1x I $\quad \ldots \ldots \ldots \ldots \ldots \ldots \ldots \ldots \ldots \ldots \ldots$ Page 92

Appendix II $\quad \ldots \ldots \ldots \ldots \ldots \ldots \ldots \ldots \ldots \ldots$ Pago 95

Appendix III $\ldots \ldots \ldots \ldots \ldots \ldots \ldots \ldots \ldots \ldots$ Page 97

VIII. Bibllography ..................... Pago 99 


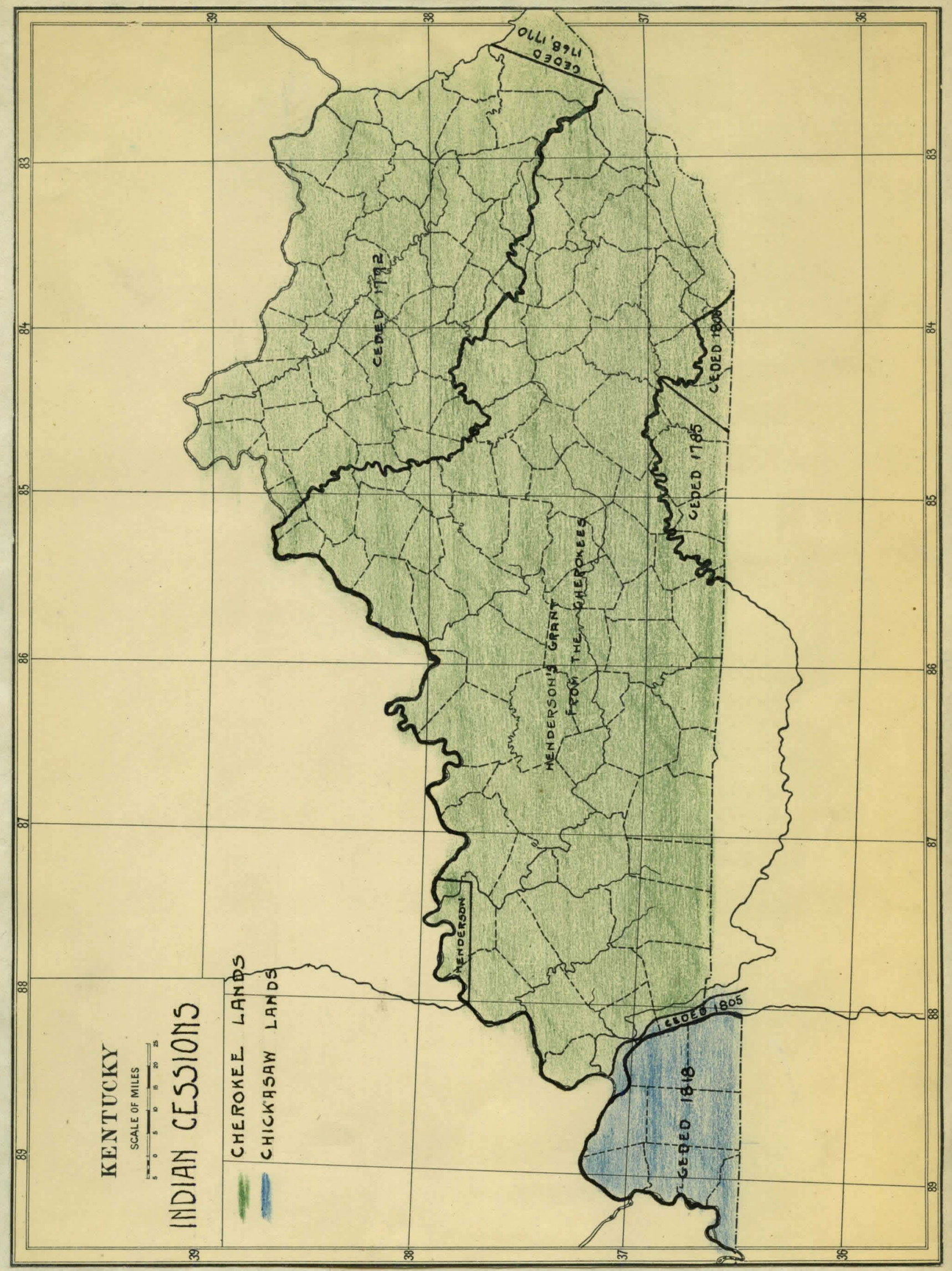


IAND LAWS OF KENTUCEY

INTRODUCTION 
This thesis follows the growth of settlement in Kentucky from the time of her birth as a state in seventeen hundred and ninety-two, to the joar eighteen hundred and thirty-seren, a period during which all of the land within her borders was opened for settlement. It does not pretend to relate a complete story of the march across Kentrack, but only to tell the important stages as revealed by the laws governing appropriating of land.

There were no ${ }^{(1)}$ Indian towns or villages within the boundaries of what is now Kentucky, but certain tribes had definite hunting grounds. The Cherobees were one of these tribes. (2) on the borders of Virginia and North Carolina the ancient limits of the Cherolees seem to be shrouded in ....doubt and confusion ....After following Catama river to its source in the Blue Ridge, the course of the mountains is pursued to the Great Iron Mountain range near Floyd Court House, Virginia, thence to Kanawha ....down that stream to Ohio. Later they claimed down Ohio to the ridge dirlding Cumberland and Tennessee." At the treaty of Hopewell in 1785, Chief Tassel presented a rude map on which a line was drain marking the bounds of the cherokes (3).

(1) History of North America Vol.II p.237

(2) Fifth Annual Report "Bureau of Fthuology p.141

(3) Am. State Papers "Indian Nffairs" Vol.I. pp.42 \& 431 
The line began at a point on the Ohfo above the Kentucky and ran thence to "where the Kentucky road crosses the Cumberland River," (PIneville), thence south to Chimney Top Mountain. Governor Blount of the Territory South of the Ohio, stated that the Cherokees had their chief hunting grounds further south on the Holston and Tennessee and rarely visited Cumberland waters. These Indians themselves admitted their loose hold there, for (4)Colonel Tathem of RIchmond reported that he heard a Cherokee warrior say to Bichard Henderson, "You, Carolina Dick, have deceived your people. You told them wo sold you the Cumberland lands. Wo only sold you our claim, they belong to our brothers, the Chlckasars."

The Chfckasaws had become masters of Cumberland waters ${ }^{(5)}$ by defeating the shawnees who had their villages there, and sweeping them across the 0h10. The Cherokees had helped in the fighting so they claimed some rights to the territory. Hajor Robert Rogers of the English army, traveling in America before 1765 writes, "Below the Ohio River, on the east side of the Mississippi, down to its mouth the country is owned and Inhabited by the Chickasams for nearly two hundred miles to the eastward .... their chlef settlements are on the banks of the Oh10, on the streams that flow into It from the east. The Taneseo is wholly uninhabited below the mountains to where it joins the ohio but the country upon it is claimed by the Chickasams."
(4) ibid.p637
(5) Malone, J.H. "The Chickasan Nation" pp.302 \& 304 
The northern Iroquols claimed the lands lying between the Ohio and Tennessee Rivers as part of the $1 x$ Oh10 Valley territory.

The Indians had relinquished most of their rights to Kentucky soll before the time of her statehood. The Iroquols ceded to the English crown all their pretensions to lands south of the Ohio at the treaty of Fort stanmix. The Chickasams ceded to Virginia their claim to the cumberland lands in 1782. The Cherokees ceded land to Virginia and R1chard Henderson.

At the treaty of Hard Labor in 1768, the Cherokees agreed that the southwest boundary of Virginia should be (6) "a Iine extending from the point where the northern line of North Carolina Intersects the Cherokee hunting grounds about thirty-six miles east of Long Island in the Holston River; and thence extending in a direct course north by east to Chiswe 11!'s mine on the east bank of the Kenhowa River, and thence down that stream to its junction with the Ohio." By the treaty of Lochaber, South Carolina, October 18, 17̄̄o, this boundary was made a straight line from a point on the Holst on six miles east of Iong Island to the mouth of the Great Kanawha. In 1772, by treaty and purchase, the line extended west from White Top Mountain in latitude $36^{\circ} 30^{\prime}$. When Richard Henderson desired to establish a 
colony in Kentucky; he applied to the Cherokees for a so land. Although their claim to the land desired was shadowy, these Indians commanded the path from Virginia and the Carolinas to Kentucky, 80 Henderson thought it best to negotiate with them and to settle the land territory armed with a deed of cession. His company met twelve hundred Cherokees at $(7)$ sfcamore shouls on the Wautauga in March 1775. For fifty thous and dollars worth of cloth, clothing, utens118, ornaments and flrearms, the Indians sold him an Immense tract including all the country lying between the Kentucky and Cumberland Rivers, and an approach to it through Poweli's Valley. Such purchases of land from the Indians by private individuals had been inhibited by a royal proclamation of King George III under date of October 7, 1763, so Henders on was not allowed to keep this tract long. It was taken over by Virginia and North Carolina as inherited Crown Lands after the Revolution. But $(8)$ because he hed been "at very great expense in making a purchase of the cherokee Indians" and because the commonwealth was "Ilkely to recelve great advantage therefrom," Henderson was granted compensation 0 18ewhere. The Virginia legislature decreed that: "All that tract of land ... beginning at the mouth of Green iliver, thence ruming up the same twelve and a half miles, when roduced to a straight line, thence running at right angles with the said reduced lines twelve and half miles on each side the said river, thence running lines from the termination of the line 
extended on each side the said Green piver at right angles with the same, till the said IInes intersect the Ohio which sald Ohio shall be the western boundary of said tract, be grented to Richard Henderson and company." Virginia respected the Indian claims within her borders. Her general land act passed in 1779, states, (9) "No entry or location of land shall be admitted within the country and limits of the Cherokee Indians .... or on lands reserved by act of assembly for any particular nation or tribe of Indians or on the lands granted by law to Richard Henderson and company or in that tract of country reserved by resolution of the general assembly for the benefit of troops serving in the present war."

This last mentioned "reserved tract" was (10) "bounded by the Green river and a south east course from the head there of to the Cumberland Mountains; with the said mountains to the Carolina Iine, with the Carolina line to the Cherokee or reneseo river, with sald river to the Ohio river, and with the Ohio to the said Green river."

Kentucky land had been bargained for and had been granted in various ways by the state of Virginia before Kentucky became a state. The settling of these old Virginia grants, the extinguishing of the Indians' title to their remaining hunting grounds, and the sale of these lands by Kentucky makes a complicated and interesting story.

(9) Hening "Statutes at Large" Vol.10 p.54
(10) Ibid. p.56 
THE KENTUCKY IAND OFFICE 


$$
N-O-T-I-C-E
$$

Is hereby given that on Monday, the 9th day of July next, at Mr. M'Gowan's tavern in Lexington the Land office for the state of Kentucky will be opened for the purpose of receiving Plattes and Certificates where due attention will be given.

\section{Baker Ewing, Re. I. off.}

June 28th, 1792 .

The machinery for administering the sale of public land was an important part of the new state government. The Kentucky Gazette of June 30, 1792, carried the following announcement. "Yesterday ended the first session of the General assembly, during which they passed the following laws viz.

11. An act for establishing a land office

20. An act concerning Surveyors

32. In act authorizing the Governor to appoint Survejors to the reserved military lands.

The Kentucky Land Office was created June 27,1792(I) and Baker Bwing was appointed Register. A surveyor was

(1) Act of June 27,1792. Iittell "Statute Law of Kentucky" Vol. 1 p.75 
appointed by the governor for each of the counties, The Iar required that the register deliver to the secretary of state his bond for five thousand dollars for five jears. He was to hold office during good behavior, with no stated salary, but in this new country the fees collected would certainly amount to a goodly sum especlally when(2) "all persons chargeable with any fees for services in the register's office shall discharge the same in specie at the rate of eight and four pence per hundred for tobacco." Tobacco had been the usual medium of exchange in Virginia transactions. By an act of December 22, 1792 , the treasurer of the state was ordered to pay the register five shillings for 1ssuing a grant. After $1796^{(3)}$ this officer was put on the civil list with an annual salery of two hundred pounds, * and was required to account to the state auditor for all fees collocted for any service paying them into thetreasury every $81 x$ months. There was a penalty of tro thous and pounds for fallure to make such an accounting. If the register desired to extend credit to any person, he did so at his own risk, all fees being accounted for if paid in cash.

(2) Lct of Dec.22,1792. Istte11 "Statute Lan of Kentucky"

(3) Let of Dec.14,1796. 1bia. Vol. 1 p.160

* Stated as $\$ 1000$. In schedule of Dec. 20,1800 . 
The following list gives the principal fees of the land office.(4)

Register's Feos.

For receiving plat and certificate, recording same and issuing the grant, where the survey does not exceed 400 acres - $\$ 1.12 \frac{1}{2}$

For every 100 acres exceoding 400

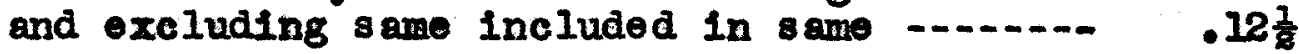

Entering a caveat or copy there of -.... .25

For a copy of any grant or patent of land

4 search for anything and for reading-- . $12 \frac{1}{2}$

Copy of plat or certificate

CopJ of warrant with asa1gnment....... .17

Copy of warrant

Recelving relinquishment or copy ....... .17

Recording power of attorney for

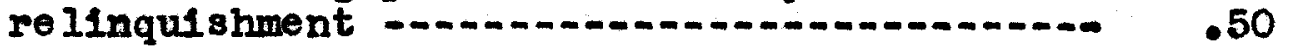
Surveror's Fees. If these were not paid they could be collected by the sheriff.

For every survey by him plainly bounded as the law directs - for a plat of such survey upon delivering of plat where survey shall not exced 400 acres $\ldots$

For every survey contained in one

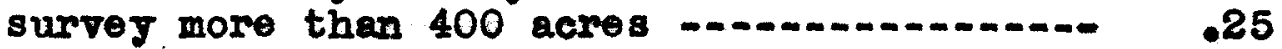

For surveying a lot in town ..................

Where surveyor is stopped or otherwise hindered from finfishing a survey begun- 2.50

(4) Lct of Dec.22,1798."Acts of General Assembly" 1798 p.138 Let of De0.20,1800. Ifttell "Statute Law" 
For running a dividing line ........... $\$ 2.00$

For re-survey of land n............... 4.00

One plat made of survejs of several

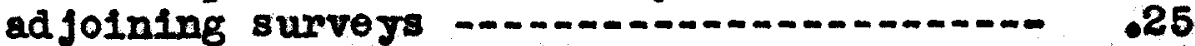

Dividing line between counties ten miles or under (straight)

Every mile over ten

For receiving warrant of survey and giving recelpt -.17

Recording certificate from comnissioners of any district for land

allowed them

Making an entry or copy

Making a copy of plat or certificate of surveg

Every connected plat originalij made out, each plat over and above services on the ground -.... 1.00

Every single plat from fleld notes -.. 1.00

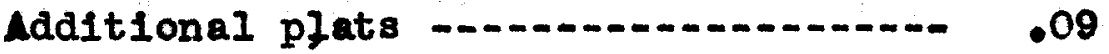

Additional copy of connected plat -.... .50

Recording all offlcial surveys -...... .09

Survey or record in book all connections of surveys officially made. each plat (not over4)

Over four

For every three poles actually run an 1.00 Processloning land (per diam) -....... 2.00

Patents were to be issued by the Kentucky Land Office just as they had been issued in Virginla. In liay 1779(5) the

(5) Let of May 1779. Hening "Statutes at Large" -V01. 10 p.52 
Virginia ceneral assemblJ had passed "An act for establishing a Iand office, and ascertaining the terms and manner of granting waste and unappropriated lands. This statute provided, "That any person may acquire title to so much waste and unappropriated land 28 he or sho shall desire to purchase, on paying the consideration of forty pounds for every hundred acres, and so in proportion for a greater or smaller quantity, and obtaining certificate from the publick auditors in the following manner: The consideration money shall be paid into the hands of the treasurer, who shall thereupon give to the purchaser a recelpt for the payment, specifying the purpose it was made for, which being delivered to the auditors, they shall give to such person a certificate thereof. with the quantity of land he or she is thereby entitled to .... upon application .... the register shall grant .... a printed marrant under his hand and the seal of his office, specifying the quantity of land and the rights upon which it is due, authorizing any surveyor ... to lay off and survey the same, and shall regularly enter and record .... all such certificates and the warrants issued thereupon, which warrants shall be always good and valid unt1l executed by actual survey, or oxchanged. ... Frery person having a land warrant and desirous of locating the same on any particular waste and unappropriated lands shall lodge such warrant with the chief survejor of the county. The party shall direct the location there of .... which location shall bear date the day on which it shall be made, and shall 
be entered by the surveyor in a book ........ Every chief survejor shall proceed with all practicable despatch to survey all lands entered for in his office ....... He shall ........ within three months after making the survey, deliver... a fair and true plat and certificate of such survey ..... Irery person for whom ...... lands shall be so located and laid off shall within twelve months ......return the plat and certificate of the said survey into the land office together with the warrant .... When any grant shall have been finally completed the register shall cause the plat and certificate of survey on which the grant is founded to be exactly entered and recorded ... (and) shallmake out a grant by way of deed poll to the party having right."

A settler was also allowed a pre-emption

right (6) to one thous and more acres for marking and improving his regular grant.

The land office promptiy started to put the land data in order. Kentucks like Virginia disposed of her land in irregular tracts without government survey. The patent or grant referred to the Iines actually run out on the ground rather then to the courses and lines named in the returns. (7) "The original marks and living monuments constitute the survey. Uncertainty arises when corners or marks on the ground are lost. These, restored by recollection of witnesses or by reputation, are the best evidences for settling boundaries."

(6) Ifttell \& Swigert "Digest of Statute Law" p.713 (7) Dembitr "Land Titles" Vol.1 p.19 
"In Kentucky, ${ }^{(8)}$ he who claimed title under a grant had the burden of proof to show what had been granted." He could not, as in Virginia, get a grant to a largo acreage and subtract the number of acres granted to others under another survey, but had to definitely locate and account for all previous surveys in the tract.

In 1792 , all Virginia grants ${ }^{(9)}$ relating to lands west of the Big Sandy were traneferred to Kentucky and placed in the custody of the register of the land office. As time went on, the logislature passed various acts to enable this office to collect data and koep track of land granted. "The survejor of Kentucky County in many cases did not enter the number of the warrant in the locations made. Many warrants were lost or mislald(10)." This meant that people were living on land to which they could not prove the right of possession. The county surveyors of the commonwealth refused to certify that warrants for these locations had been issued and then lost or mislald, because they had never come into their possession. The General Assembay had to legalize these clatms by a legislative act authorizing the county survegors to certify plats with date_of location and to state that warrants had not come to their possession. The register was then to receive the plat without the number of the warrant or warrants being specified, and to issue patents.

At this time, provision was made for the re-survey of old grants to cedtify errors in the previous

(8) 1bid. Vol. I p.4I

(9) Ifttell "Statute of Law" Vol. 1 p. 75

(10) Ibld. Vol. I p.216 
survey if greater then the surplus of five acres for every one hundred. The person desiring the re-surveg must "advertise his intentions at the door of the court house on two several court days - also having given notice to owners of adjoining land." He must then present the petition to the court of the county in which the lands lie. The court con order a re-survey at the charge of the petitioning party according to the original or authentic title papers. If the general court certifies that the new survey is reasonable, the person can demand a register's recelpt. Iny one objecting to the patent of the new survey must file complaint within six months. Re-surveys were necessary because of the many overlappling claims in the old gants. sometimes, the taker-up of land found that he had contracted for a larger claim than he could manage to aoquire. In that case, he could disclain(11) part of the land and relinquish right to it by making an entry of the tract. The title of the relinquished land then reverted to the state.

In 1797, the General Assembly (12) instructed the register to "apply to the executive of Virginia for all original papers in the register's office on which titlos of land in Kentucky depend ... and monies recelved by him for plats and cortificates on which patents were not issued." 
At the next $4 \mathrm{ssembly}{ }^{(13)}$ the authorities were also instructed to apply to the surve jors of the Virginia state and continental lines residing in Kentucky for the entries In their offices made on military warrants. The time which Virginia had stipulated for holding the reserved tract as military lands had expired. This territory was about to be opened to settlers so it was necessary to locate outstanding survegs and so to avold future litigation due to over-lapping claims. Uany plats and certificates of land wich wero brought from Virginia were ljing in the Kentucky land office. In 1798, the General sssembly directed the (14) register to secure an order for the return of fees paid to Virginia by the owmers of these plats and certificates and to carry them into grant as speedily as possible.

When more land was apened for patenting, the land office had increasing difficulty in keeping a systematic record of transactions. So, in 1799, an act of the General Assembly ordered all survejors in Kentucky to transcribe, within eight months ${ }^{(15)}$ all original entries in a fair and legible hand and in good books, well bound in calf and deposit same with the register of the land office."

Two jears after the general land law was passed opening up most of the vacant country in the state to settlers, It was necessary to order(16) all clerks of the county courts

(13) Ibld - Vol. 1 p. 118

(14) "Acts of General Assembly" $1798-$ p.33

(15) Iittell - "Statute of $\mathrm{L}_{\mathrm{Q}} \mathrm{w}^{\mathrm{m}}$ Vol. 2 p.302

(16) 1b1d - Vol: 3 p. 60 
to transmit to the register all certificates given for vacant land.

The first constitution of Kentucky contained a provision concerning land titles which, in the light of future fudicial proceedings in the state, was exceedingly unfortunate. Article V, section 3 , states (17) "The supreme Court shall have original and final juridiction in all cases respecting the titles to land under the present land laws of Virginia Including those .... for the district of Kentucky, and in all cases concerning contracts for land prior to the establishing of those titles." John Marshall, in comenting on this constitution, declared it to be nearly perfect and thoroughly republican in its apparent features except for this giving of original jurisdiction in land cases to the Appellate Court. To take such cases out of the sphere of the more frequent and more accessible general courts proved most "mischievous and expensive" in practice. The land laws of Virginia were in force in the new state to protect the rights acquired by settlers of 1779-1791 but no new grants could now be acquired under them. The survejors of milltary land were continued and county survejors appointed, whose business was to make the official surveys to be recorded in the land office. The pecullar ${ }^{(19)}$ land laws of Kentucky are based

(17) Young, Bennett H. - "History and Texts of the Three Constitutions of Kentucky" 1890

(18) Littell \& Swigert - "Digest" ${ }^{33}$ - Vol. I, p.712 (19) Jillson, W.R. - " Kentucky Land Grants" - p.3 
on the Virginia act of 1779 "as modified and interpreted according to the principles of law and equity contained in decisions of the appellate court." Although the original Virginia act was drawn by George Mason, one of her most able statesmen, it was amended before its passage, in such a way as to destroy system in procuring patents and consequently caused much confusion over conflicting claims in Kentucky•

At this time taxes on land were two shillings for a hundred acres, the same tax as paid on a working slave. 


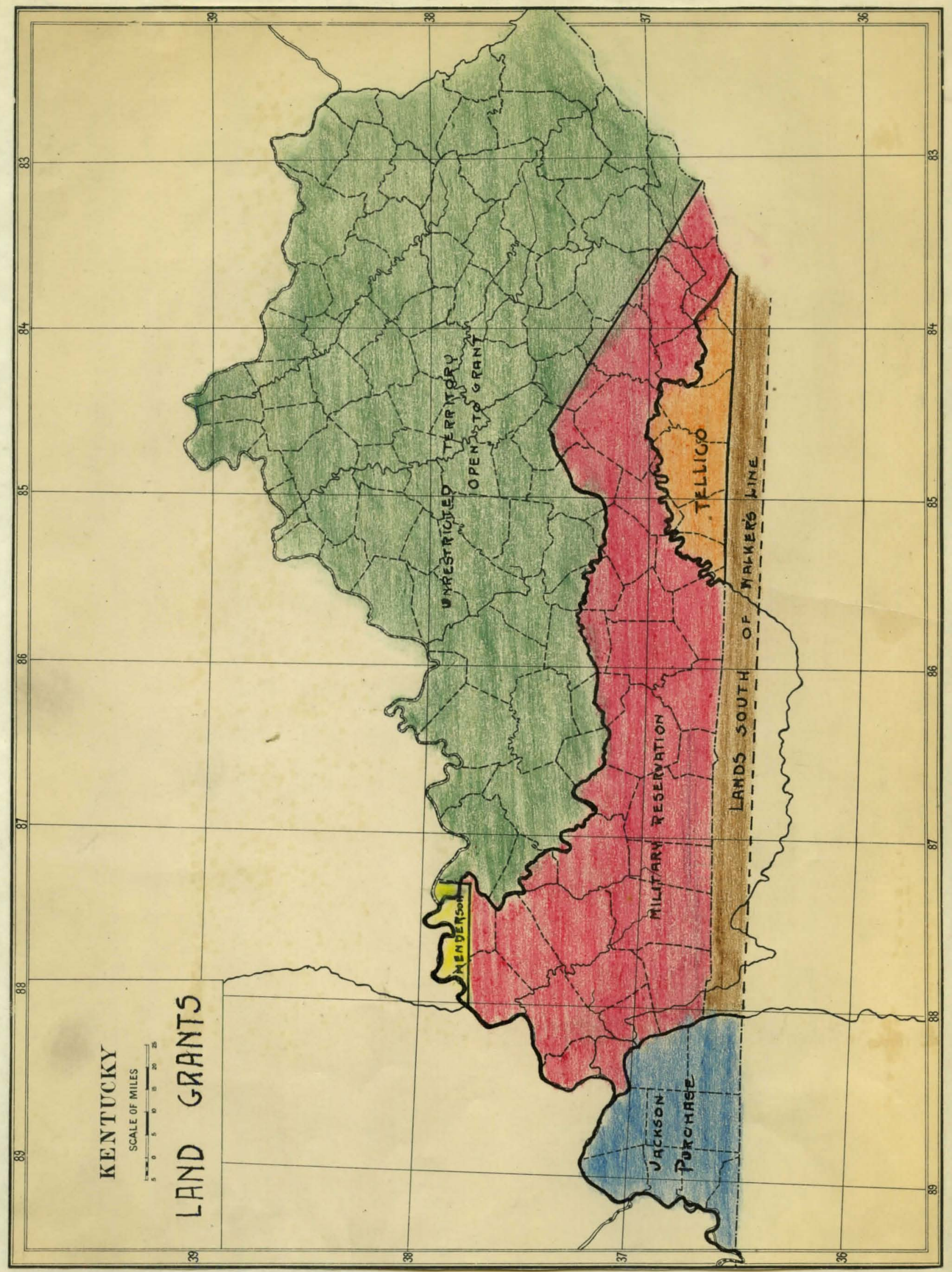


In consldering the land laws of Kentucky, it is Important to note that these laws were not all enacted by the Kentucky General Assembly, but in many cases the general principles and often the actual laws were those of the perent state, Virginia, offices for the disposal of public land had been opened in the district of Kentucky. George May, the surveyor for the new county of Jeffers on arrived from Virginia and opened his office at Cox's station in November 1782. Colonel Richard Clough Anderson was chosen princlpal surreyor of bounty lands to be entered for the Virginia officers and soldiers of the continental line. He opened the office of the virginia military district at the Falls on July 20, 1784.

Virginia had fallod to survey her public lands, a fallure destined to bear sorry fruitage for the new state. Sometimes as many as five or six patents covered the same plece of land. Court action for generations has not succeeded in clearing them all out. Many and varlous survejors ran Iines for claims in the country which later becam Kentucky. These survegs had to be recorded at Richmond. A lurking Indien or a treacherous mountain stream often prevented the survegor's return and gave rise to mang claims with unregistered surveys. This meant land litigation brought to the attention

(1) Collins -"History of Kentucky" Vol.II p.368 
of the Virginia assembly. Harassed by this ever-recurring trouble, these legislators were quite willing to grant a liberal county government to this wilderness of theirs beyond the mountains, as early as 1776, that it might have authority to settle some of these disputes. In 1792, they were not reluctent to see Kentucky become an independent state, able, thereafter to settle all her own troubles. The complications of Kentuch's land laws produced a large crop of eminent lawyers who gained wealth and prestige through taking up disputed claims and through contingent foes. Kentucky's first constitution contains this provision - (2) 111 laws which on the first day of June one thousand seven hundred and ninety two were in Virginia and which are of a general nature, and not local to that state, and not repugnant to this constitution, nor to the laws which have been enacted by the legislature of this commonwelth, shall be in force within this state, unt1l the shall bo altered or repealed by the ceneral 18 sembly." Thus did Joung Kentucky inherit land laws from old Virginia. During the time she was petitioning for atatehood, Kentucky entered into a "Compact with Virginia". When the first contitution was adopted 1t contained this clauses 3 ) "The compant with the state of Virginia, subject to such alterations as may bo made therein agreeably to the mode prescribed by the said compact, shall be considered as part

(2) Pirst Constitution of Kentucky -Articlo VI, Soc.8 Iitte 11 \& swigert - "Digest" - p.35

(3) Ib1a - p. 37 
of this constitution." And this is what the compact says about land. (4) "AlI private rights and interests of lands within the said district, derived from the laws of Virginia prior to such separation, shall remain valid and secure under the laws of the proposed state and shall be determined by the laws now existing in that state." "....The lands within the proposed state of non-resident proprietors, shall not in any case be taxed higher than the lands of residenta, at any time ... nor shall a neglect of cultivation or 1mprovement of any land within (Kentucky) subject such non-residents to forfeiture or other penalty within the term of six years."

Thus Kentucky validated the Virginia land grants within her borders, ${ }^{(5)} 9,564$ of which have been found recorded. Many of them were grants on military warrants given to soldiers as part payment for military service in the Rerolutionary War and in George Rogers Clark's expeditions. Virginia had promised "bounty land" in trying to ratse the six new batallions required of her during the Revolution. (6) She promlsed to those who enlisted to serve through the war, the following portions of land to be given at the close of the war, or whensoever discharged, to the officers and soldiers who shall engage in the sald service or to their representatives if slain by the enemy, to wit: To

(4) Ibid - p.18

(5) Jilison - "Kentucky Land Grants" - p.7

* Seo Appendix 1.

(6) Hening - "Virginia Statutes at Large" V01.9 p.179 
every non-commissioned officer or soldier, one hundred acres, to every ensign one hundred and fifty acres, to every lie utenant two hundred acres, to every captain three hundred acres, to every major four hundred acres, to every lieutenantcolonel, four hundred and fifty acres, to every colonel five hundred acres (7) she promised to the soldiers of ceneral clark who "enlisted and continued ti.l the taking of sereral posts in the Illinols country" two hundred acres each. These grants were very near to the hearts of the poople of Kentucky. On the third day after the first House of Representatives had been assembled, Mr. Bedinger of Bourbon County geve notice that next day he would move for loave to bring in a bill giving further time to officors and soldiers of the Virginia state and Continental lines to locate and survey their bounty lands.

\section{Is late as December 17, 1796 a Virginia lam} was acknowledged in force which states:- (8) " 111 surveys of waste and unappropriated land made upon western waters before January 1, 1778, by any county surveyor combissioned by william and Mary college .... acting in conformity with laws then in force, tracts not exceeding four hundred acres, for milltary service either from the King of Great Britain or any former governor of Virginia are good and valld." soldiers were to be given the lands if the survegs were returned within twelve months. In 1797 the time expired when the only surveys legal in the country south of Groen River were those

(7) Ibld - Vol. 10 p.26

(8) Ifttell - "Statute Law of Kentucks" V01.1 p.387 
made on military warrants. Even after this land was opened for general settlement, tracts could be taken up on these old warrants for many years if the surveys had been made. (9) An act of February 12, 1798, states that any one found guilty of making a survey on a military land warrant "issued by the state of Virginia on which an entry was not made on or before Hay 1, 1792, unless the same shall have been ... authorized by law, and all persons aiding or assisting therein shall forfeit five hundred dollars, to be recovered in .... court." The passage of such an act seems to indicate deliberate attempts to lay a military warrant on land taken up and so secure it without paying the state purchase price. Eariy land "speculation".

Land certifioates or warrants were sometimes circulated as specie and so left the possession of the old soldiers or their heirs. Two later enactments indicate there must have been traffic in these military warrants and misuse of them. One act ${ }^{(10)}$ made any military warrant vold if knowingly laid on land granted to another settler. Another stated that the commonwealth would expect fees and payment for any land taken up,as head right land even if a military warrant were later laid upon it.

An announcement appearing in the Kentucky Gazette for August 11, 1792, seems to be the advert1sement of an early real estate broker and 1llustrates how warrants

(9) Iittell - "Statute of Law - Vol. 2 p. 109. (10) Digest - Dec.23, 1803. Ifttell - Vol. 3 p. 135. 
changed hands.

\section{For Sale}

At a very low price.

A settlement and Preemption, containing fourteon hundred acres of land, lying within the settlement near Stroud's station.

I w111 also purchase a quantity of Treasury land warrants and paper money of all kinds.

\section{John Fowler.}

Julg 7, 1792.

Iftigation arising from the claims of holders of 0ld Virginia land entries was so persistent and annoying that acts out lawing them had to be passed by the General issembly. During the session of 1815-1816, this law was enacted (11) "Whereas it is represented to this General 1 ssembly and $1 \mathrm{~s}$ moreover manifest from an inspection of the books of the Register of the land office that the habit .... is now prevaling to an Injurious extend, of survejing in the name of heirs and others, entries made under Virginia Treasury office land warrants upon the unappropriated lands of th1s cormonwealth and upon lands approprlated by the good cltizens and under the laws of this commonwealth, whereby the public revenue is defrauded and the citizens aforesaid subject to embarrassment and Inquietude (therefore)".... No plat or certificate of survey which purports to be made on an entry upon a virginia Fond office treasury warrant made since October 19, 1785 shall

(11) Ifttell - "Statute of Law" Vol. 5 p. 316 
be recorded and carried into grant unless the surveyor who shall have made out the same officially certifies on it that the identical objects called for in the entry, or some of them, are embraced in the sald survey and the proprietor files an afidavit that the land called for under the survey is the same as that in the entry." False swearing was to be punished by the laws of perjury and a fine of five hunared dollers. **

* See Appendix 2. 
The tract south of Green River set aside for the satisfying of military land warrants had been reserved by Virginia only unt1I 1797. During this "closed" perlod, many immigrants with no military warrants had settled on these lands: It was early declded ${ }^{(1)}$ that "locations on is lands in the OhIo below the mouth of Green River "made on a land off 100, treasury or other warrant should bo recolved by the register, recorded, surrejed and patented. In 1795 the legislature moved ${ }^{(2)}$ to provide patents for the other settlers who had "squatted" on the milltary reservations

"Every housebeeper or free person above twenty-one years of age who is an actual settler on land not previously taken by military warrant on or before January first next shall be ontitled to hold land not excoeding two hundred acres." No salt or ore land was to be taken up with grant. Entry had to be made before August first, survey, within six months from this.date and plat returned six months from date of survej. Three persons were appointed to hear and determine the right of settlement. In surveying, the longest part of the tract was not to be
(1) IftteII- "Statute Laws of Kentucky" Vol. 1 p. 216 (2) Ib1d - Vol. 1 p. 349
* See Appendix 3. 
move than twice the width at the narrowest part. The price was thirty dollars for one hundred acres. A warning was tacked on to th1s statute - "No person shall settle on vacant land in the state in the future, with an expectation of being given preference in settlement." In Uarch, 1797, the Green River country was opened for new locations. (3) "Any widow or free male person of twentycone years of age, every other person having a family who shall settle upon vacant and unappropriated land south of Green RIver on or before July 1, 1798 and reside thereon one year, clear and fence two acres of ground and tend it in corn, shall be entitled to two and not less than one hundred acres to include such improvement," provided the settlement was not on lands ceded by Congress to any Indian tribe. The claims were to be survejed as nearly in a square intervening claims would permit. Sixty dollars was charged for one hundred acres of first rate land, forty dollars for second rate. Ho one who had taken up land under the act of 1795 could qualify under this act. The money was to be paid into the treasury within twe lve months - the plat and certificate to be returned in twe lve months. No mention was made of excepting salt and ore land.

At this same time money for the 1795 land was made payable in installments with 5\% interest. On February 10, 1798 an act practically 1dentical with that of March, 1797, was passed, but "salt

(3) IftelI -statute Laws of Kentuck" Vol. 1 p.682 
11ck or spring or one thousand acres around same laid off in a square to the cardinal points," and lands reserved for seminaries of learning, were set apart from those on which locations were allowed. This new act of course extended the time limit for settlement until July 1, 1799. The "takers up" were to get a certificate of seitlement when the comissioners sat, pay, get the auditor's quietus in twelve months and return the plat in twolve months. of course, arrangements were made for the payment of Green River land on the Installment plan. (4) Acts passed at various times allowed first for four annual installments then for nine. The dates when various installments were due were postponed sometimes for six months, sometimes for ten. Neter the general land law of 1800, (which allowed four hundred acres to be taken up) came into effect, (5) Green River settlers, who had two hundred acres or less, located and actualig settled under the former laws, could take up their extra acreage without actually residing on it. In 1805, the auditor of public accounts was ordered $^{(6)}$ to have an accounting made to show what was owing or would be due on Green River land. $A$ foe of three cents for each certificate or entry was allowed. Bvidently Kentucky was having difficulty in collecting her installments on"debts of the commonwealth for the sale of vacant lands."

The first really general Kentucky act for grants
(4) IAttell - "Statute of Law" - V01.2 pp.262-380
(5) Ibla - - Vol. 2, p. 459
(6) Ibid - Vol. 3, p. 306 
was passed by the Assembly December 20, 1800, (7) This "act for settling and lmproving the vacant lands of the Commonwolth," was offective threo months after passago. It read:- "Whereas-.- there are large quantities of vacant land which by being occupled by cltizens (of Kentucky) or citizens of the linited States or foreigners, who being thereby encouraged to reside thereon, w1ll greatiy add to the population, wealth and consequence of the commonwealth .... any free person above the afo of eighteen jears who w1ll improve, occupy and hold four hundred acres (shall bo granted land) provided he actually settles and resides thereon." The price was twenty dollars for one hundred. acres. The taker up had three months after settling to apply to the court of the county for a certificate of settlement. This certificate described the location and told the quantity of land he was entitled to claim - Green River settlers were only allowed two hundred additional acres. This certificate cost one shilling. Within twelve months from the date of the certificate, the claimant must show it to the register of the land office, pay the treasurer the twenty dollars for each one hundred acres and get a warrant for the location. Within six months from this date the warrant must be lodged with the county surveyor who survejed the land cited in the warrant within twelve months. At the expiration of this time, the survey must be returned and the regular fees paid. The length of the strip was not to exceed the breadth by more than one third unless

(7) Lttell - "Statute Law of Kentucky" V01.2, p.420 
Interrupted by prior claims.

The settler had to reside on his land two years before he received his patent, during which time no transfer or asslgnment was lawful. In all contests by settlers under this act "those who first did actually and "bona fide" settle and reside on said lands" were given preference. persons settling prior to this act could have the benefit of its provisions by obtaining a certificate of settlement before August first 1800 .

A notable fact is that foreigners were allowed to qualify for land. Five gears before this, (8) three large tracts of land of 120,000 acres each had been purchased in Pennsylvania and Kentucky for Immigrants from Wales. The principal settlement was in Hels on County, Kentucky, five miles from Salt River. This is a point of interest because at that time allens, though allowed to acquire land by purchase, had been declared by the supreme Court of the Inited States to be unable to acquire it by inheritance. (9) The fact that if a person who had applied for land died before the grant was issued it would descend to his heirs, further complicated alien holdings. If the heirs were allens, the next of kin who could qualify would recelve 1t. On December 22, 1800 a law was passed ${ }^{(10)}$ "allowing allens to hold lands in fee imple in the commonwealth," after they had been residents for two jears.

Due to the careless way Kentucky allowed

(8) Collins -"History of Kentucky" Vold 1, p.24

(9) Condensed Reports-Supreme Court of U.S. 4 (The aton) 506 (10) Ky Gazette-Dec.22,1800. Ifttell - V01.2 p.399 
grants to be located, claims continued to over lap. Sometimes one of the claimants would fall to pay the price for his lands and they would revert to the state. The question arose - Would the other and overlapping claimant lose his right to own that acreage? It was decided ${ }^{(11)}$ he should be given a prior right to obtain a patent for that land upon paying the state price for 1t, and the ceneral Assembly enacted such a lav for his protection.

Sometimes attempts would be made to lay a military warrant on land known to be held by other settlers under Kentucky acts. The General Assembly voted the claim of the holder-of-the-military warrant to be "null and vold and his warrent rendered invalid by the act of knowingly laying It on the land of a settler." Furthermore, he could not get another patent for his military claims until ofter nine months had elapsed.

$$
\text { Times were so hard for the settlers that an }
$$
act for their rollef was arranged. "Mhereas ... many c1tizens ...ore unable...because of their late emigration and the scarcity of money, to discharge the state price now due, lands can be paid for in equal annual installments on or before November $1,1810, "$ the first instaliment to be due November 1, 1804. S1x per cent interest was to be charged on each installment from the time such debt should become due, the interest to be paid with the installment. The state reserved the right to pass laws to coerce payment (11) IAttell - "Statute of Law" Vol. 3 pp. 132, 134. (12) 1bid - Vol. 3 p 132. 
of Installments. "All lands for which a certificate has been or may be granted by virtue of any of the afore recited acts shall remain subject to the demand of the state for the money due therefor as head-right land notwithstanding any ommission or neglect to carry same into grant and a subsequent appropriatienthere of by m1litary warrant or otherwise."

(13).

Later, no claim was allowed which interfered with any prior claim. The overlapping acreage could, however be re-located. This would have given an opening for some shrewd patentee under the older grants when land sold for a high price, to re-locate under the twenty dollar law. This was expressiy forbidden in the act.

The next year the legislature modified its land act. From and after March 1, 1806, (14) no county court in Kentucky could grant any certificate for settlement or other right. To prevent imposition being practiced on the court, any applicant had to prove by three disinterested witnesses, (1) that he or she was actually living on the land and had lived there with family, household furniture and personal property for one month before making application and (2) that he or she was a person of good famo, "provided nevertheless that no certificate shall be granted to any bachelor or female other than a widow."

Because of the difficulties of communication in

(13) Ibid - Vol, 3, p. 195

(14) Ib1d - Vol, 3, p. 306 
scattered places, some persons did not find out that the general land law had been repealed soon enough to get their certificates in timo. Another law (15) had to bo made assuring any one who was a bona fide settler before June 1, 1806, of a certificate.

At the 1806 session of the General Assembly, the legislators began to inquire anxiousiy into the "debts due the commonwealth from the sale of racant land." Money was scarce and the men did not w1sh to put too heavy a burden upon the settlers, so it was declded that the money due could be paid in twolve annual installments with six per cent interest. If the money was not then paid the lands were to be disposed of. (16) Within fourteen days after December list in every year, the auditor of public accounts was ordered to transmit to the register a list of certificates and entries upon removed certificates upon which installments were not paid, showing the amount due the state. On the third Monday of December the register was to sell such lands "at public auction at the state house for ready money." The sales were to be made at the rate of not less than fifty tracts a day.

In 1808 and for several years thereafter the (17) legislature promptly and annually suspended these sales for a year. Before this time land had been sold for taxes under authority of two acts one passed December 21, 1800, the other

(15) $\quad$ ib1d - Vol. 3, p. 359.

(16) 1bid - Vol. 3, pp. 385, 406.

(17) "Aots of General Assembly" 1809-10 p.53 
December 19, 1801 .

111 of the racant land of Kentucky was not again thrown open for grants until the yoar 1815. In February of that yoar anothor general land law was enacted. (18)

in the older act in order to avold litigation.

\section{"Whereas there are large quantities of waste} and unappropriated lands in this Commonwealth, the granting of which w1ll promote population, increase the annual revenue and erect a fund for public use: ...from and ofter the last day of February, 1815, any person except allens may acquire title to so much waste and unappropriated lands as he or she shall desire to purchase, on paying the consideration of twenty dollars for every hundred acres." The Treasurer, upon receiving payment for the land, would give a recelpt specifying the purpose for which the money was paid. Upon delivery of this recelpt to the Auditor, that officer would give a certificate stating the quartity of land. The Register would then take the cert1ficate and give a printed warrant specifying the quantity of land, and authorize the county surveyor to survey it and lay it off. This warrant was valid until executed by actual survey or exchanged. The county surveyor was Instructed to make most careful records of surveys applied for and survey them strictiy in the order of application. Only actual settlers could ask for surveys before January 1, 1816. The proprietor could have his survey made on any

(18) Acts of General Assembly" - 1814-15 - p. 398 . 
waste and vacant lands he might point out, but he was to buy not less than one hundred fifty acres unless joined around by lines of prior existing claims."

The officials in charge of isiuing patents were ordered to be most careful in keeping records and most prompt and diligent in making surveys. Bvery survey was to be "bounded plainly by marlced trees, stones or stakes except where a water course or ancient marked line shall be a boundary. They shall be made in the presence of two house-keepers resident in the county not interested in the survey. . The survejor shall upon finishing the survey and before leaving the ground specify in his field notes for whom the survey was made, the number of the warrant and have same attested by the said house-keepers, these field notes to be as carefully preserved and as open to inspection as any other books and papers. The surveyor must make a fair and true plat and certiflcate of the survey within three months ... and at the foot (must appear) the names of the housekeepers, chain-carriers and marker signed by him as to the number of acres in full."

The plat, certificate and warrant were to be lodged with the Register within one year from the time of survey and to remain there six months, then the patent would be issued in the usual form. When the warrant was carried into grant, the Register was to write on its face "satisfied" or "exchanged" .

To prevent doubts as to title, the actual survey was to be considered the commencement of title and 
an early date of survey took precedence over an elder grant with a jounger survey. "For quieting litigation, all entriea heretofore made and all titles founded upon surveys heretefore made authorized by laws then in force, are superior to survegs made upon warrants obtained by virtue of this act, notwithstanding ang alleged vagueness in the entries or certificates on which the surveys were founded." No lands could be appropriated which had escheated to the commonwealth formon-payment of taxes, etc., on which were claimed by the Indians. This act was to be in force for none but actual settlers until December 1 , 1815, and was to continue in force unt11 January 1, 1818. Koney accruing from the land sold was to be reserved in the treasury for further action. Laws allowing persons to relinquish a claim or part of a claim were suspended. In the winter of 1820 , the price of vacant (19)

land was reduced to ten dollars for a hundred acres. This did not apply to land west of the Tennessee River or south of Walker's line.

The state still had trouble collecting the instaliments due for land becaure the settlers were poor indeed. At each session of the General Assembly indulgences were passed. These were of various kinds some allowing a longer time over which to make payments; some discounting the interest due if paid within a certain time limit; others forbidding the buying up of land 
stricken off for debt and allowing it to revert to the state to be held for redemption, or allowing only an original settler to redeem land stricken of to the state. Conflicting claims due to careless surveying and the hap-hazard locating of entries, caused the General Assembly to take action for the protection of actual settlers. These laws are known as the "Occupying claimant Laws" The one passed February 27, 1797 states: "Whereas from the frequency of interfering clatms to land, and the unsettled state of the country; it often happens that titles lay a long time dormant, and many persons deducing a fair title from the record, settle themselves on land supposing it to be their own, from which they may be afterwards evicted by a title paramount thereto; and it is just that the proprietor of the better title shall pay the occupying claimant of the land for all valuable improvements made thereon; and also that the occupying claimant shall satisfy the real owner ... for all damages; ... therefore... every person ... evicted from the land ... shall be exempt... from all and every species of action." The court was to have the value of lasting improvements and damages estimated and to enter them as judgment against the persons and see that it was paid. The principles of this law were not new but were acted upon in the colony of Virginia in 1661.

On January 31, 1812 "an act to amend an act 
concerning Occupying Claimants of Land" was "passed according to the provisions of the constitution, notwithstanding the Governor's objections." This act again asserted the right of an occupant who had "peaceably seated or Improved" lands to compensation for such improvements and further provided that when the Improvements amounted to three-fourths of the value of the unimproved land, and the rightful owner was not willing to expend so much, that the occupant should pay the difference and own the land. If the improvements did not - amount to more than three fourths of the value of the land, the right owner of the land should pay the occupant his mone J• 
41.

LAWS GOVERNING LATER ACQUISITIONS

THE GHEROKEE LANDS 
When Kentucky was admitted to the Union the Cherokee Indians still owned lands in the southeastern part of the state Iying between the Cumberland River and the Carolina line. Naturally, it was desired to acquire this territory so that white settlers could take up grants there. It was a matter to bo undertaken by the ${ }^{(1)}$ Federal Government.

After the Revolution, a report on the condition of the Southern Indians was brought into Congress. It contained stories of fights and depredations. (B) Congress decided that five comissioners should be elected to treat with the Cherokees and other southern Indians who had been at war with the United States "for the purpose of making peace with them, receiving them into the favor and protection of the United States and removing as far as may be all causes of future contention and quarrels." On November $26,1785,(3)$ the commissioners met with the Indians at HopeweII on Keowee in South Carolina and made a treaty by which land was secured from the Cherokees. Article four of the treaty states:- (4) "The boundary allotted to the Cherokees for their hunting grounds between the said Indians and the citizens of the United
(1) U.S.Bureau Am.Fthnology - Vol.18 pt.2 p. 553
(2) "Journal of the Continental Congress" Vol. 10 p.74
(3) American State Papers "Indian Affairs" Vol. 1 p.42
(4) "Journal of the Continental Congress" Vol. 10 p.56 
states .... shall be the following viz. beginning at the mouth of Duck River on the Tennessee, thence running N.F. to the ridge dividing the waters running into the Cumberland from those running into the Tennessee, thence eastwardy along the said ridge to a N.E. Iine to be run which shall strike the river Cumberland forty miles above Nashvilie, thence along the said line to the river; thence up said river to the ford where the Kentucky road crosses the river thence to Campbell's line near Cumberland Gap." Thence the line was continued marking a south and southe ast boundary. There was some misunderstanding as to the meaning of "a N.F. line to be run which shall strike the river Cumberland forty miles above Nashville." There were two interpretations. One was the literal construction making the line strike the river at a point of the river which was forty miles above Nashville. The other, made the sentence read "a N.B. line shall be run, (which shall strike the river (umberland), forty miles above Nashville." This latter reading gave more land to the white man and was the one used when the line was finally run. So by "Hopewe Il", the Cherokees ceded more than half of their land in Kentucky and retained only a tiny patch in the extreme southeast. The treaty provided that "If any citizen of the United States or other person not being an Indian shall attempt to settle on ang of the lands westward or southward (of the line) which are hereby allotted to the Indians for their hunting grounds, 
or have already settled and will not remove from the same within $s i x$ months after the ratification of this treaty, such person shall forfelt the protection of the United States and the Indians may punish him or not as the please."

William Blount, ${ }^{(5)}$ as the representative of the state of North Carolina, objected to the prom visions of the treaty because the commissioners had assigned land to the Indians which the legislature of North Carolina had appropriated to discharge bounty claims of officars and soldiers of that state. Georgia also protested. The commissioners, however, insisted "that a steady adherence to the treaty alone can insure confidence in the justice of Congress and remove all causes of further contention and quarrels." When the head men of the cherokees returned home from Hopewe II, they found that the treaty displeased the young warriors who. wished to keep the Cumberland lands. It is therefore not surprising that the treaty was not carried out for some time. The line along Cumberland waters was not established unt1l 1797 when General Winchester ran 1t according to the interpretation which gave the United states more land.

The pioneers enbroaghed upon the lands of the Indians despite the assurance of the Central

(5) American state Papers "Indian Affairs" Vol.1 pp. 38, 44, 637. 
Government that the Indians could drive the white settlers off. (6) whites should remove from Cherokee lands as well as proclamations by the Governor of Virginia to the same effect were unheeded. The Indians complained. Henry Knox, Secretary of War, wrote to the President. "It has been proved that the said treaty (Hopewe 11) has been entirely disregarded by the white people inhabiting the frontiers styling themselves the state of Franklin."*

Settlers continued to pour into the west. In 1803, the legislature of Tennessee sent a memorial to Congress asking that some measure be adopted for extinguishing Indian claims in that state. Whereupon, (7) Congress appropriated the sum of fifteen thousand dollars to procure "Indian claims lying within the limits of the United States." This of course included the Cheroke claims in Kentucky.

These Indians were reluctant to part with more of their hunting grounds. A delegation ${ }^{(8)}$ he aded by Chief Glass had even gone to the capital in June, 1801, to interview the secretary of War. They reminded him of the promise made at the treaty talk of 1798, that no more land cessions would be asked of them. They desired to know whether the United States or the settlers had

(6) Ibid Vol. I pp. 19, 41

* A proposed state in what is now east Tennes see.

(7) History of Congress - "Debates in Congress"

(8) Fifth Annual Report-Bureau of Ethnology p.85 
gotten the land already sold. The secretary of War told them that there was no desire to purchase more land from them unless they were anxious to sell; that Kentucky and Tennessee had been formed out of the lands already bought from the Cherokees and that the main object of a future proposed treaty would be to secure a right of way for roads through their country in order to maintain communication between detached white settlements.

After several fruitless conferences, the commissioners who had been appointed to treat with the Indians in regard to extinguishing their claims in Tennessee, Kentucky and Georg1a, met the head men of the Cherokees at ${ }^{(9)}$ Tellico block-house and arranged "for a cession of all land which they formerly claimed north of the following boundary (a line drawn) from the mouth of Duck River up the main stream ... to the junction of the fork at the head of which Fort Nash stood, with the main south fork, thence a direct course to a point on the Tennessee River bant opposite the Hiwasse River ... up the midale of the Tennessee (is lands being left to the Cherokees) to the mouth of the Clinch, up the clinch to the former boundary line, reserving to the use of the Cherokees a small tract at or be low the mouth of the clinch, to a notable rock on the

(9) American State Papers "Indian Affairs" Vol. I p.369 
north bank of the Tennessee in view from Southwest point, thence course at right angles with the River to the Cumberland Road, thence eastwardy along the same to the bank of the Clinch River and down the same to the mouth thereof, together with two other sections of one square mile each, one of which is at the foot of Cumberland Mountain at and near the place where the turnpike gate now stands; the other on the North bank where the Cherokee Tolotiski now lives."

For this land, the Indians were to receive immediate if three thous and dollars in valuable merchandise, eleven thousand dollars within ninety days of the ratification of the treaty by the United states, and three thousand dollars annuity from the day of signing the treaty (October 25, 1805). Part of the eleven thous and dollars would be paid in machinery if the Indians so desired. The treaties of Hopewell and Tellico blockhouse together wiped out all Cherokee claims to any land In Kentucky, and the state could now dispose of their holdings in southeastern Kentucky between the Cumberland River and the Tennessee line.

As soon as the news spread that the government had acquired the Cherokee lands, white settlers promptly moved in. Some had been established there when the tract was st11l Indian hunting ground. In Kentucky, ( 19 the

(10) Iftteil - "Statute of Law" VoL. P. Act of Dec. 26,1805. 
General Aasembly decreed "no certificate shall be granted for or removed upon any land the Indian title to which may have been extinguished since the year 1794 or may hereafter be extinguished by treaty or otherwise, until further order of the legis lature."

These (11) lands ceded in 1805 became known as the "Tellico Lands". They were opened for registra-. tion to old and new settlers by the same legirlative act of January 31, 1810, effective April first (12) "... Every free white male, or widow, or other unmarried female, above the age of eighteen years, who may have actually settled and resided, and who may hereafter actually settle and reside, for the space of $s 1 x$ months, on any waste and unappropriated lands, ... acquired by the treaty of Tellico, (may) apply to the circuit court of the county ... and upon proving ... by two respectable and disinterested witnesses, that he or she has settled and resided... for the space of six months, be entitled to ... not exceeding two, nor less than one hundred acres." Salt springs, mines, minerals with one thousand acres could not be so appropriated. The settler had to pay a shilling for a certificate wherein was given a description of his "Iocation". The certificate, accompanied by the payment for the land at the rate of forty dollars for each one hundred acres, had to be returned within twelve months to get a warrant. The warrant must then be surveyed within twelve months and the plat and certifi-

(II) Jillson "Kentucky Land Grants" p.9 * * The name is now Jellico. (12) Acts of General Assembiy- 1809-10 - p. 130 
cate recorded and returned to the register's office, whereupon the patent would be issued. The length of the strip taken up could not be more than one third greater than its breadth. If any settler did not take up his lands in one gear, another settler of a year's residence on Tellico lands, was permitted to take up the location. Money recelved from the sale of this section was to be spent to buy arms for the militia.

In $1811,{ }^{(13)}$ provision was made whereby Tellico grants could be pald for in four annual installments with six per cent interest. Holdings could be sold for fallure to pay. The price of Tellico lands was later reduced to ${ }^{(14)}$ twenty dollars for a hundred acres payable in three oqual annual installments, but no person who had secured a grant under the other Tellico act could buy under this one.

From the time of opening the lands for grant on, through many years, the Acts of the General Assembly of Kentucky are punctuated with acts "for the relief of Tellico settlers," promising rebate of interest postponing payments or the like.

In 1831, the General Assembly decided that (15) since lands of the Telifco tract and those south of Green River were "poor and of little value," the settlers could pay at the rate of five dollars for a hundred acres. If partial payments had boen made on any claim, the balance
(13) "Acts"
(14) "1cts"
1810-11 - p. 115
(15) "Acta" 1831
(Act of Jan.31, 1811)
1811-12 - p. 214
p. 103 
still due was to be determined by calculating the value of the entire acreage of the tract at five dollars a hundred and subtracting the amount already paid from this figure.

4 short time afterward an act was passed $(16)$

-... to repeal the law now in existence in relation to Headright settlers and dispose of the balance of the debt due from this class of debtors to purposes of internal improvements." This was to be done by having the owners of headright certificate claims file certificates in the county clerk's office showing the balance due the Commonwealth; then the county court was to determine on what public highways within the county, the money or labor "arising or due from sald Head-right debtors be appropriated;" and to appoint "overseers authorized to collect either in money or labor the said balances and recelpt for the same." Any head-right certificate not patented within two years was to be forfeited to the state. The court could relleve widows or poor persons from paying. Succeding legislatures, as usual, put off from time to time the day of executing this law in regard to taking up head-right land within two years.

There are (17) five hundred and seventy-two grants in the Tellico records. The Cheroke lands ceded to the United States lay in the present counties of Cumberland,

(16) "Acts" 1832-33 p. 167 (Act of Jan, 31, 1833)

(17) Jillson -"Kentucky Land Grants" p. $\theta$. 
Clint on, Wayne, Russe 1l, Pulask1, McCreary, Whitleg, Knox and Bell. Among the "Tellico Grants" are found recorded scattered entries from other parts of the state. Mr. Jills on does not know why such claims were recorded as Tellico. There were probably careless and dishonest clerks then as now. 
The Chickasaw Indiens he ld the country from the ridge in western Kentucky dividing Cumberland waters from Tennessee waters to the Mississippi River. They were a brave and superior nation and showed dignity and pride in their dealings with the white people. The g liked the things the white traders had to sell and bought more than they could pay for. The traders encouraged the Indians to get deeper and deeper in debt for there was always good security - land which the whites coveted. In 1805, the Chickasaw nation(18) "embarassed by heavy debts due to their merchants and traders," ceded for the consideration of twenty thousand dollars, a vast territory stretching from the Oh10, along the dividing ridge between Cumberland and Tennessee many miles south. Just a narrow strip of the land was in Kentucky, The treaty gives the cession as "the tract of country within the following bounds - Beginning on the left bank of the OhIo at the point where the present Indian boundary adjoins same; thence down the left bank of Ohio to the Tennessee river; thence up the main ch annel of the Tennessee river to the mouth of Duck river." This takes the ceded territory into Tennessee where the southern boundary is described. The eastern boundary runs into Kentucky again, - "northwardly to the great ridge dividing the waters running into the Tennessee from 
those running into Cumberland river 80 as to include all the waters running into Elk river, thence along the top of the sald great ridge to the place of the beginning."

The Chickasars still held their hunting grounds beyond the Tennessee. The authority of Virginia had already touched this territory. George Rogers Clark had established Fort Jefferson at the Iron Banks on the Mississipp1 in 1780. This had been done to strengthen the claim of the United States to the Mississipp1 as its western boundary. The Indians had been angry about this fort on their hunting grounds.

(19) Virginia had also granted some of the lands west of the Tennessee River to officers, soldiers and treasury warrant clesmants. The Kentucky General Assembly now turned its attention to securing this country from the Indians. On February 11, 1809, a resolution was adopted concerning the advisability of extinguishing the Indian titie.

The resolution was sent to Washington, but no attention was recelved from the General Government. A jear later anothor communication was irafted. (2Q) people of Kentucky taking Into view the Indian encumbrance by treaty with the United states on the lands within this state below the Tennessee River, a large

(19) "Acts of General Assembly" 1809-10 p. 41 (20) ibid. 
portion of which had been by the state of Virginia sold to officers and soldiers and treasury warrant claimants who are deprived of the use thereor, and taking into view the probable willingness of the Indiens to extinguish the encumbrance, and that the United states having funds more than sufficient arising from the sale of lands on the northwest s1de of the Ohio River which were ceded by the state of Virginia subsequently to her sales aforesaid; passed a resolution in their General Assembly, February 11, 1809 in order to obtain the attention of the General Government. But it is presumed the executive of the United States hath not embraced the same views." The Assembly ordered further correspondence with the government for procuring the extinguishwent of Indian claims at costs and charges of the Onfted States. A similar resolution was roted January 31, 1811. Then the legislature became occupied with war, the wearing of home manufactures and militia, so the matter was dropped.

After the war with England was over, the matter of the lands befond the Tennessee was revived. At last after much prodding, the United States government authorized a commission to negotiate with the Indians for their lands east of the Mississippi. Is arc She lby and Andrew Jacks on arranged a treaty Oct. 19, 1818, at the treaty ground east of 01d Town. It was approved by Congress in 1819. ${ }^{(21)}$ The Kentucky portion of

(21) Jillson - "Kentucky Land Grants" p. 11. 
of the land became known as the Jacks on Purchase. The treaty read - (22) ".. the Chlckasaw nation of Indians cede to the United States of America (with exception of reservation herein mentioned), all claim or title which the said nation have to the land lying north of the south boundary of the state of Tennessee which is bounded south by the thirty fifth degree of Morth latitude and which land hereby ceded lies within the following boundary viz: Beginning on the Tennessee fiver about thirty-five miles by water below Colonel George Colbert's ferry where the thirty fifth degree north latitude strikes the same; thence due west with said degree of north latitude to where it cuts the Mississippi at or near Chickasam Bluffs; thence up the said Mississippi river to the mouth of the ohio, thence up the ohio river to the mouth of the Tennessee River, thence up the Tennessee to the place of the beginning." "Article 3 .. The commissioners of the United states agree to allow said nation twenty thousand dollars per annum for fifteen consecutive years to be paid annualiy." Other special monies were paid to Individuals for personal claims. "Article 4 "... For the benefit of the poor and warriors of said nation, ... a tract of land containing four square miles to includo a salt lick or spring on or near the river Sandy, a branch of. 
the Tennessee and within the land hereby ceded be reserved ... so as to include the best timber. (They may) "lease said land to citizens of the United States for a reasonable quantity of salt to be paid annually to the sald nation."

Some venturesome souls immediately moved in to locate sites on the new land. They were sternly rebuked by the General Assembly declaring (23) "no entry can be made on any portion of land within the late Chickasaw Indian boundary ... It is not lawful to receive the survey or issue patents on 1t." Kentucks had learned about land complications in a tedious and expensive school and she did not Intend to repeat the mistakes of former years. The Jacks on Purchase land was to be handied and sold carefully and accurately. There was much to be done before offering it for sale.

In his message to the General Assembly December 7, 1819, acting governor Gabriel slaughter inquired, (24) "Would not our lands in the west lately acquired by treaty with the Indians together with other racant lands judiciously disposed of form a fund competent to the education of the youth of the state?" No action was taken on this suggestion.

The General Assembly took formatd steps towards the occupation of the Chickasdw country by an act of February 14, 1880. (25) At that time they voted "that

(23) "Acts of General Assembly" 1818-19 p. 606

(24) "Journal of the Senate" 1819 - p. 16

(25) Ifttell \& Swigert - "Digest of Statute Law of $\mathrm{Ky}^{\prime \prime} \mathrm{p} .816$ 
a fit person be appointed by joint vote of both houses to superintend the survey of the lands west of the Tennessee ...., to lay off and divide the land .... by north and south lines running according to the true meridian, and by others crosing at right angles so as to form townships of six miles square undess where the course of navigable rivers may render this impracticable ... The corners of the townships (were) to be marked with progressive numbers ... and each township divided into sections contalning six hundred forty acres each, by running through the same five lines parallel to the east boundary lines of the townships beginning at the distance of one mile from each other ... Bach section (was) to be marked with a stone or tree. A general plat (was) to be made exhibiting, the situation of each township and section, stone or post marked therein, ... the situation of mill sites; ... the

- crossing of water courses; and the quality of the so11." Also It was "to describe the situation of all mines, salt springs or licks and all remarkable places and whether there was any person residing in any section or township and also report the land as first second or third rate." The surveyor was to receive two dollars for every mile he necessarily ran.

William T. Henderson was appointed to make the survey. The following December he was (26) "authorized to publish at his own expense and costs and for his own benefit, the map and survey of the land west of the

(B) "Acts" 1819-20 p. 145

(Act of Dec. 19,1820) 
Tennessee River to which he may add any notes of explanation deemed necessary and ... have the exelusive right of publishing and vending the maps for ter years."

These carefully laid off townships and sections, however, were not unencumbered. In citing to the national government tho advantages of extinguishing the Indian title to the land, various warrants emanating from the Virginia issembly were mentioned. Virginia had acted as if all the land to the Mississippi. was hers to dispose of. Kentucky undertook to provide for these claims. (27) "Be it enacted that ... the nurveyor of lands set apart for the satisfaction of the legal bounties of officers and soldiers of the Virginia line on state establishment, be and is required to procure chain cerriers and markers and to survey without delay all entries made in his office prior to May I, 1792, on military warrants and shall make out a full and fair connexion of surveys so made showing where and how they interfere with the tomships and sections as laid off by William T. Henderson, surveyor for the state." No grant was to be issued until six months after the plat and cortificate of survey was registered. The land west of the Tennessee was to be taxed the same as other land, beginning March 10, 1821. The act also provided that "if persons entitled to a plat and survey do not take the same out of the surveyor's office and file it with the register on or before January first, 1823, the right of such person to the 
entry on which the survey wax made w1ll be considered lapsed and forfeited to the state." The surveyor did not get them all recorded in time, so the General Assembly gave him a further time of one year ${ }^{(28)}$ to perform his duties. No patent was to be issued on any such claims unt11 after January 1, 1823. (29) In its October seasion of 1783 , the

"General Assembly of Virginia authorized the deputation of officers of the Virginia lines, on state as well as on continental establishment to lay off four thousand acres of land, in such manner and form as they may judge most beneficial, for a town, on the Mississippl or waters there of." On August 2, 1784, they located four thous and acres for the town upon the Mississippi, including the "Iron Banks". The Kentucky legis lature now in 1820 had to take up the story of this town upon the Iron Banks because a majority of its trustees had "departed this life before the trust reposed in them was executed." William Croghan, the surviving trustee, together with Joseph Rogers Underwood, Richard Taylor Junior, William Montgomery, and David L. Mckee were appointed to have a survey made for the four thous and acres, record it in the office of the surveyor of lands set apart for military bounty on state establishment, return plat and certificate to the register and receive their grant. The trustees could not sell or dispose of this land until further disposition was made by the 
legislature, but they were required forthwith to proceed to lay out town with "convenient lots, avenues, streets and alleys, to number the lots and name the streets, alleys and avenues, reserving for the public square and public buildings what is expedient and right provided that not more than three hundred acres shall be laid out in lots not exceeding one acre each." A plat of the town was to be made out and recorded. The trustees were authorized to adopt the necessary rules and regulations for the town government. When lots were ready to be sold, the month's notice was to be given in the newspapers, then not more than one hundred lots of half an acre each were to be disposed of and the proceeds paid into the state treasury. Thus the town of Columbus was started.

These town trustees were bonded for fifty thousand dollars. One year later $(30)$ this bond required of the trustees was repealed and they were instructed to appoint a treasurer for the town who would then be bonded. At the same time it was decided that notes on the Bank of the Commonwealth or the Bank of Kentucky would be received in payment for land. All monies arising from the sale of land in Columbus or of adjolning lands donated by the State of Virginia to her state and continental lines was to be appropriated for the use and benefit of those soldiers and their heirs.

As usual, claimants were slow in returning plats and cortificates of survey made upon these westeon (30)"Digest" p6 823. 
lands by right of old Virginia military warrants (previous to May 1, 1792), and various (31) acts were passed extending the time until June $1,1826$.

All previous grants in the Purchase now having been taken care of, the first sale of land was authorized on December 21, 1821, under the title (32) "An act providing for the sale of vacant lands west of the Tennessee River." This sale was to be conducted by the register of the land office on the first Monday of September, 1822, at Princeton, Caldwe 11 County. The time and place of the sale was to be advertised in certain designated newspapers in Kentucky, and in papers in North Carolina and Virginia four months before it wes held. If enough bidders did not appear, the register could suspend the sale. On no account could he buy lands for himself either directiy or indirectly. The crier employed for the sale, was to sell the odd sections in certain specified townships for ready money to the highest bidder. Notes of the state and Commonwealth's bank, gold, silver, or notes of any specie paying bank in the United States would be accepted in payment. The cashier of the Branch Bank of the Commonwealth at Princeton was designated to receive the purchase money, to be held subject to the order of the President and directors of the principal bank. Not more than a quarter section could be sold at one time. No section included in the military survey could be sold.

The act also contained this statement, very im-

(31) "Digest" - p.830 - "Acts" 1825 p.182 
portant and very significant because of the agitation then being stirred up over Kentucky's "Occupying Claimant Laws". "Many people have settled on lands west of the Tennessee River hoping some liberal provision would be made for them by their government. Actual settler on the land to be sold are entitled to reasonable compensation for improvements, or to hold the same five years rent free, according to the choice of the purchaser." This clause was in line with Kentucky's other occupying claimant laws which always contended that a citizen (33) "Peacefully seated" on land which he thought was his, should be entitled to payment for permanent improvements and could not be put off the site until he had gathered his standing crops, if another person appeared who had a proved, prior title to the land. Money paid on the land by occupier could be transferred to another claim. Richard Biddle was one of the settlers who had given up his claim to John Green, and the two parties had adjusted their difficulties. The higher state courts had always supported the validity of the occupying claimant laws. On the eve of the opening of the new lands west of the Tennessee River where old warrants were known to be outstanding, the Green-Blddle case was carried to the Supreme Court of the United States where it was ${ }^{(34)}$ ruled that these laws were null and vold.

Governor John Adair in his message to the

(33) "Acts of General Assembly"1811-12,p.117

(34) Condensed Report Supreme Court of U.S. 5(Whe at on) p. 373 
senate, October $16,1821,(35)$ counsel to support the validity of the laws and urged the opening of communication with Virginia for the purpose of "amicable explanations". He stated that, "The legislature never doubted 1ts authority to pass all of them. This authority has been affirmed by our highest judicial tribunal in every instance where the question has been made ... The validity of some of these acts has been called in question before the Supreme Court upon the ground of their imputed repugnancy to the compact between Kentucky and Virginia. Virginia has never complained and has never asked for a commission. Kentucky has Intended strictly to observe its compact because it is incorporated in both constitutions, one of them adopted after the (occupying claimant) act of 1797."

The part of the compact referred to was Section 7 which says, (36) "All private rights and interests of lands ... derived from the laws of Virginia prior to... separation shall remain valid and secure under the laws of the proposed state and shall be determined by the laws now existing in this state (Virginia)." In Section twe lve It was agreed that any disputed point arising out of the . compact should be decided by a specially appointed commission, two chosen by Kentucky, two by Virginia and two chosen by the other four.

After considering the matter the General Assembly decided to transmit the report of the committee 
to the senators and representatives in Washington and also to send a commission to Virginia.

Henry Clay and George M. Bibb went to Virginia. The next May they were ready to report. (37)

Virginia comunicated by Benjamin Watkins Leigh the resolution of her legislature "touching the unsatisfied claims of officers and soldiers of the Virginia state line to bounties in lands." Kentucky was required either, "to recognize by law the right to locate unsatisfied military warrants west of the Tennessee River, and to permit the holders of those already located on bad land or so as to interfere with other claims, to withdraw the same and survey them on any land in the district west of the Tennessee River;" or to appoint a board of commissioners authorized to decide the points of difference between Kentucky and Virginia. It was felt that Kentucky could not possibly accede to the first proposition so it was deemed expedient to appoint the board of commissioners by joint vote of the senate and house.

Henry Clay met Benjamin Watkins Ieigh on June 5, 1822, and reported the result of their conference at the fall meting of the General Assembly. (38) They had decided to suggest that the four commissioners for Kentucky and Virginia meet in washingt on on the fourth Monday in January, 1823. Washingt on was chosen because there would be many eminent people there at that time from

(37) "Acts" 1822 - p. 15

(38) "Journal of Senate 1822 - p. 30 
whom to choose the other two members of the board of arbitration.

Jacob Burnet, a supreme court judge of Ohio, and Hugh I. White, a supreme court judge of Tennessee, were elected ${ }^{(39)}$ commissioners from Kentucky. Henry Clay and John Rowan were appointed counselors to the commission. The Treasurer was ordered to advance six thousand dollars for the expenses and pay of the delegates. Clay and Rowan (40) "determined to proceed to Washington without delay in order to get there at the time the Virginia comissioners would arrive who had so short a distance to go." Jacob Burnet also proceeded to Washington but the Honorable Hugh I. White, for good and sufficient reasons, declined to accept the appointment as commissioner. The two Kentuckians were ready "without loss of time to supply the vacancy."

of course Kentucky had gone ahead "not doubting that Virginia would ratify the solemn act of her commissioners." Imagine their consternation when she refused to do sol The House of Delegates approved the appointing of commissioners to settle the dispute but the Senate would not approve. The House of Delegates of Virginia sent a courteous note to the Governor of Kentucky (41) hoping "that" friendly relations between the two states be unimpaired" and that "the wisdom and good dispositions of future legislatures may yet succeed in removing all causes of difference between the two states."

(39) "Acts" $1822-\mathrm{p} .152$

(40) "Journal of the House" 1823 p.53

(41) Ibid p.54 
And there in Washington sat Henry Clay, John Rowan and Jaeob Burnet the "fit counsel" and the honorable commissioner from thé state of Kentucky. They had remained there knowing of the difficulty in the virginia senate because the "thought it their duty to remain at the ir post and thus exhibit to the world that ... the fault was not on the side of Kentucks." Burnet was paid seven hundred and forty-four dollars and proceeded to take his muddy journey back to Cincinnati.

The Supreme Court of the United states again passed on the occupying claimant laws and again declared thom (42) nuIl and vold. This time they oven went bejond the compact with Virginia and fell back upon the "Constitution of the United States which declares (43) "no state shall pass any law impairing the obligation of contracts." The decision was handed down very late in the term at a session when only four of the seven justices were sitting. Thus we have a decision against the Kentucky occupying claimant laws really made by a minority of the Supreme Court. Quoting from Rowan's "Vindication" (44) "The opinion was formed by three only of the seven justices. Had one of the three, instead of concurring therein concured with the dissentient judge, the position of things in Kentucky would not have been disturbed, so that in effect, the rights of half a million people are to be afflictingly changed and controlled by the opinion of one

(42) Condensed Report supreme Court of U.S. Vol.5 (Whe aton)

(43) Journal of House" (KY) 1823-24 p.13 pp. 369-399 
single individual momber of the court."

The people of Kentucky were by no means

unanimous in wanting the occupying claimant laws uphe Id. (45) When a vote was taken in the legislature upon the sending of a remonstrance to Congress against the supreme Court decision, the voting for and against was pretty equel. The complaint was sent and both national houses considered it and gave strong indications that Kentucky's

"cause was considered the cause of every other state and every ... defender of the true principles of our Federal Union would ... support such ... changes and reforms in the Judicial Department of the Federal Govemment as may be necessary to defend the states from further encroachment of that powerful tribunal."

About this time there was ${ }^{(47)}$ a movement of settlers from Kentucky to Illinols and Missouri. The governor stated it was his belief that the insecurity folt by the cultivators of the soll was the cause of the extensive emigration. For several jears the governors continued to urge action against the ${ }^{(48)}$ "encroachments of the Federal authorities upon the sovereignty of our states and the rights of our citizens through the medium of the there is

judiciary," but "ture no record of further definite action taken within the period ending in 1837. In Carroll's statutes of Kentucky, revised to 1930, faws in

(45) 1bid - pp.389-396

(46) "Acts" 1824-25 - p.281

(47) Coling - "History of Kentucky" p. 31

(48) "Journal of House" 1828-29 p.15 
force) (49) we find "If any person belleving himself to be the owner by reason of a claim in law or equity, the foundation of which being of public record, hath or shall hereafter peacefully seat himse if and Improve any land, but which land shall .... be decided to belong to another, the value of the improvements shall be paid by the successful party to the occupant." Kentucky kept her occupying claimant laws.

On June 1, 1825, the Receiver of Public Moneys for the Land District west of the Tennessee River, opened his office at Wardsborough, Calloway County. The General Assembly had willed ${ }^{(50)}$ that this recelver be appointed to sell the public land. Every three months he was to pay over his recelpts to the Branch Bank of the Commonwealth at Princeton. On the first Monday in October, 1825, he was to offer "all unappropriated sections in a public sale to the highest bidder." Not more than a quarter section could be sold at a time and if it did not bring one dollar an acre, the plot was to be stricken off to the state. This land could be bought later for one dollar an acre. Section fourteen of the act authorizing the sale, declared "If any lands sold... shall be taken from a purchaser ... by prior claim ... the person shall receive the amount of the original purchase money .... without interest."

$$
\text { "An act (51) to reduce the price of vacant }
$$

lands west of the Tennessee river to actual settlers, and

(49) Carroll -"Statutes of Kentucky" section 3728 p.729 (50) "Acts" 1824-25 p.85

(51) "Acts of General Assembly" 1828-29 
more effectively to encourage the settlement ond improvement of sald land" was passed by the General Assembly in January, 1829. ".... Hereafter it shall be lawful for any actual and bona fide settler with a family who at the passage of this act resides within the land district west of the Tennessee River to enter ... one quarter section of land at twenty-five cents per acre." The offer was open to any person who became a settler within twe lve months. Iosa but not more than a quarter section could be taken. No one but a settler could enter the tract for nine months. (52) If two people were living on the same quarter section and both wanted to take it up under the act, the elder settler was to have it provided the junior was left in peaceable possession of his 1mprovement for two years.

"To prevent further conflicting land cleims and to secure to Seaters and Improvers a preference of location to lands improved by them," ${ }^{(53)}$ any person intending to take up/grant the land a settler had cultivated, was required to give the occupant three full months notice so he himself could take up the land if he so desired. The Recelver of Public Monies ${ }^{(54)}$ for the land district west of the Tennessee, failed to make satisfactory settlement of his accounts, until ordered by the General Assembly to bring his books before a commission appointed to settle with him on or before the first Monday in May, 1832 . 
Neter February 20, 1835, (55) the price of land west of the Tennessee was reduced to twelve and a half cents an acre. The settler was not protected in more than two quarter sections and he must reside on one of them. In 1838, Bath County ${ }^{(56)}$ was allowed to f1x the price of her remoining vacant land but it must not be less than that allowed by law. The 1slands owned by Kentucky in the Mississippl River and Cesh Island in the Ohio were sold ${ }^{(57)}$ at auction to the highest bidder in 1837, but they could not be sold for less than twenty-five cents an acre.

By the year eighteen hundred and thirty-seven, all of the public land owned by Kentucky had been offered for sale. The land office continued to function for some years afterwards but the main body of public land law and policy had been written and determined by 1837..

$\begin{array}{llll}\text { (55) } & \text { "Acts" } & 1834-35 & \text { p. } 182 \\ \text { (56) } & \text { "Acts" } & 1837-38 & \text { p. } 30 \\ \text { (57) } & \text { "Acts" } & 1837-38 & \text { p. } 194\end{array}$ 
72.

SPECIAI IAND GRANTS

THE SURRENDERED TERRITORY 
For years the boundary between Virginia and North Carolina, and later between Kentucky and Tennessee was in dispute. Colonial charters gave the parallel of thirty six degrees and thirty minutes as the place of division. Surveying parties, made up of men from both Virginia and North Carolina spent days in the wilderness locating this line. The surveyors would disagree, separate and each group run a line it deemed correct. Dr. Walker's line of 1779-80 was regarded as the boundary until an accurate survey was made. This Iine fell from six to ten miles north of the true parallel. (1) "The line was accurately established by Robert Alexander and Iuke Monsell in 1819 following legislative appointment." In 1820 commissioners from Kentucky and Tennessee came to an agreement about the land lying between the two lines. The land was in Tennessee but Kentucky was given the right to issue grants for all territory north of $36^{\circ}$ and $30^{\circ}$ and east of the Tennessee River. Surveys of this land are not recorded but the papers are found in file boxes in the land office.

An act opening these lands to settlement was passed December 28, 1824. (2) "From and after the first

(I) Jillson - "Kentucky Land Grants" p.I1.

(2) "Acts" - 1824-25- p. 68. 
day of March next, any person ... may acquire as much vacant ... land in Tennessee between Walker's line and the latitude thirty-six degrees thirty minutes north and betweon the Cumberland River near Ohy's river, and the Tennesseo River, as he or she, may desire to purchase upon the payment into the Treasury of this state ... twenty dollars for every ond hundred acres." They maght acquire land between Walker's line and thirty-six degrees thirty minutes and Cumberland River and part of Cumberland Mountain for ten dollars for a hundred acres.

The survey was to be made within three months, plat in the Register's office six months from date of survey. Actual settlers on the land at the time of opening it had exclusive rights to appropriate their places of settlement and one hundred acres. The money was not assigned to any particular use. Later the price was reduced $^{(3)}$ and any person except an alien could acquire title to land south of Walker's line for five dollars a hundred acres. No survegs were to be for less than fifty acres and no surveys were made west of the Tennessee River. This rate was in effect about a year when the price was raised (4) to ten dollars a hundred acres. A capable mathematician was to be secured to mark the Iine $36^{\circ} 30^{\prime}$. There have been 4,583 grants in Walker's Addition.
(3) Ibid - p. 129
(4) "Acts" - 1825- p. 135
(5) Jils on "Kentucky Land Grants" p. II 
75.

THE SEMINARY GRNWTS 
A few jears after Kentucky became a state, a Presbyterian school was established and called Kentucky Academy. George Washington, John Adams and Aaron Burr were among the easterners who subscribed to it. In 1798, the General Assembly granted this academy $81 x$ thousand acres of land. (6) Ilke quantities were given to Franklin and Salem academies and to Iexington and Jefferson seminaries. This started the seminary grants. These appropriations were made from (7) lands in Kentucky on the south side of the Cumberland River below Obey's River now vacant and unappropriated or on which at this time there is no actual settior under the Green River grants." They were reserved by the General 4ssembly "to be appropriated as it may hereafter from time to time see fit, to the use of seminaries of learning throughout different parts of the commonwealth." By an act of 1808 , a seminary was to be established in each county. (8) The county surveyor marked off the seminary lands when they were chosen. Unfortunately they had a hard time collecting fees for this service and a bill had to pass the legislature requiring the trustees of the institutions to pay for the surveying service. Some of the seminaries were slow in

(6) Iftell "Statute Laws of Kentucky" Vol. 2 pp.107/8 (7) IAttell \& Bwigert "Digest" p.II

(8) Iittell Statute Law Vol. 3 p. 440 
taking up their grants, so in 1811, (9) the justices of the county courts of Knox, Boone, Est1ll and Clay, had to petition to be allowed six months more to procure more donation lands to make up their six thousand acres. They were allowed to locate "on any vacant land except Tellico lands, and lands lying west of the dividing ridge between Cumberland and Tennessee Rivers." No one seminary ${ }^{(10)}$ was to have more than six thousand acres. The time for locating was extended two more years. Many seminaries were "Iand poor" - having no resources sufficient to equip a plant upon these liberal acres. The General Assembly had to come to the rescue (1I) and decree that if the trustees wished to sell all or part of the lands donated for seminaries two persons (paid two dollars a day) should be emplyed to appraise the land. The land must then not be sold for less than three fourths of the appraised value. The comissioners could give deeds to the property.

After Kentucky had been thrown open to settlement as far as the Mississippi, and more and more counties formed, extra land was needed for seminary grants. So (12)

"an act appropriating a portion of the vacant lands in the district of country west of the Tennessee River for purposes of education" passed the General Assembly. When the agents of the seminaries attempted to get this land, they con-
(9) "Act "
(10)
(1i) inets
"Acts"
1810-1811
1811-1812
1811-1812
1833-34
p. 101
p. 171
p. 126
p. 378 
flicted with grants taken by actual settlers. The county courts were then allowed $(13)$ to appropriate other acreage upon any vacant land west of the Tennessee or upon is lands In the Ohio or Mississippl Rivers (as soon as the were surve yed), in place of thatrelinquished to the settlers.

(13) "Acts" $1835-36$ P. 648 
In opening up public lands for occupation it was frequently stated that no salt mine or mine of ore was to be included in the grants. These deposits then had to be obtained by special act. Salt manufacturing was an important industry in these oarly days. "Good old Kentucky salt" (14) was advertised for sale in Cincinnat1, April 15, 1794. This is typical of the salt land grants. (15) "Be it enacted that ... John Francis and Richard slavey .... be granted land for a salt works, ... (the grant to be) not less than one thous and acres ... No grant shall bo is sued until the prove to the county or circuit court of Wayne county that they have manufactured at least one thousand bushels of salt within three years of this act." The price of the land was ten dollars for a hundred acres. The grant was not to interfere with any actual settlement or to give them the rights to iron, silver or lead found thereon. "If they transfer their rights 80 as to ald in a monopoly of salt making," continued the legislative act, "the land is to revert to the state." Some early ant1-trust legislation. In order to encourage manufacturing in Kentucky the General Assembly granted ${ }^{(16)}$ to a group of trustees,

(14) Collins - "History of Kentucky" Vol, I p. 22 (15) "Acts" 1810-11 p. I13

(16) Littell - "Statute Law of KJ." Vol.2 p.290 
s1x thousand acres south of Green River to be distributed to settlers in two hundred acre tracts. Two thirds of the settlers were to manufacture wool, cotton, brass and 1ron for two years. The remaining one third weseto reside on the land for one year, clear, fence and cultivate five acres each. 
GRANTS FOR TOWNS AND FOR COUNTIES 
Two acres of land ${ }^{(17)}$ could be appropriated for every court house erected in Kentucky. Either "Iand built upon or adjacent thereto not having any house, orchard or other Imediate convenfences thereon" could be taken. The land was held by the county court in fee simple. Land was granted to trustees to establish towns. The forfeited Iands of John Connelly at Loulsville were survejed and sold at auction. The buyer was obliged to "build a dwelling house sixteen feet by twenty feet at least with a brick or stone chimney to be finished within two years of date of sale." The lots were conveyed in fee simple. If not built on/the time specified, the lot reverted to the trustees of the town who could either sell It and use the money for public works or use the lot for public purposes. In December of 1793 the General Assembly extended the time limit for builaing four years. (19) In 1808, the trustees of Louisville were ordered "to employ some good survejor to survey and make a correct plan of the town "and" to fix and establish such corner stones or other landmarks to perpetuate the arrangements of said town." This plan was to be returned to the clerk of the circuit court and thereafter streets, lots and so forth were to be regulated by the plan.

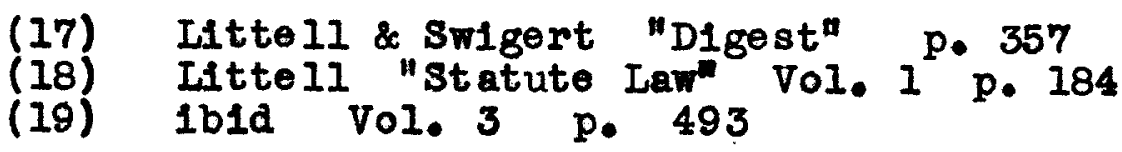


When Kentucky was young, the vacant public lands were a handy source of revenue for the counties. Many times in the "Acts" of this period appear entries for ${ }^{(20)}$ "appropriating certain vacant lands to the improvement of the public roads." One example - "... The county court of Russe 11 County ... (1s authorized) to have located, surve jed and patented, within the bounds of sald county, five thousand acres of vacant and unappropriated land, and to have power to sell and convey ... sald land to any purchaser." "... The money arising from the sale ...shall be applied to improving the public roads." Again(21) "six thousand acres in Harlan" is appropriated to bulld a bridge across straight Creek. In another place we read that Monroe County ${ }^{(22)}$ was allowed to appropriate one hundred dollars of the money recelved from the sale of vacant land to finish the court house. In 1838, the proceeds ${ }^{(23)}$ from the sale of the waste land in Clint on County was given to the County Court to go towards lessening the county levy.

$\begin{array}{lllll}\text { (20) "Acts" } & 1833-34 & \text { p. } 554 \\ \text { (21) ibid. } & 1833-34 & \text { p. } 560 \\ \text { (22) ibid } & 1836-37 & \text { p. } 74 \\ \text { (23) ibid } & 1837-38 & \text { p. } 118\end{array}$


In these early days there were no institution to care for the poor and insane and such dependents of the state. Public land solved the question of their support and grants (24) were made by the General Assembly when cases were brought to their attention.

An act for the benefit of poor widows was passed in 1820. (25) since "there ore many poor widows in this state, with numerous helpless chlldren, destitute of homes; (and) as there is vacant land now in this state, which might be of great utility to the poor and indigent; inasmuch as it is consistent with good policy, for the legislature to protect the poor widows and fatherless: Therefore, ....any widow, ... who shall make satisfactory proof ... that she has not estate in her own right to the value of one hundred dollars; (the) fact proved in open court by the testimony of two or more credible witnesses; ... the auditor.. shall issue his warrant to the treasurer .... for one hundred acres of land." Land south of Walker's line or west of the Tennessee River could not be so taken up. Land secured on these grants was not llable to "sale by execution" or "tenancy by the courtesy", it was to be a Iffe estate for the widow then to pass to her children. If there were no chlidren to inherit it, the property reverted to the state.

$\begin{array}{lll}\text { (24) "Acts" } & 1812-13 & \text { pp. 29, 30. } \\ \text { (25) "Acts" } 1820 & \text { p. } 159 .\end{array}$


THE LAND POLICY OF KENTUCKY 
The story of the securing and patenting of the public lands of Kentucky, roomplicated by the careless way entries were located, the irregular size and shape of the grants and the lack of actual ground to satisfy all entries.

Virginia had been too busy with the Revolution to have either time or monej for the surveying of her lands on western waters, so grants were carelessif located and their shape and size irregular. Survoging in a dense wilderness was no simplo undertaking, carrying a heary chain and surveying instruments for hundreds of miles was no easy job. Can we blame an eariy surveyor for cutting a length of wild grape vine measuring eleven times his own holght to be used instead of the sixty-six foot chain? of course there would be complications in the survey when the twisted grape-vine was straightened out on the ground. Can we condemn a man for paddling a cance up a river looking for a notable land mark from which to locate a survey rather than cutting his way through the wilderness soeking the exact spot mentioned in an entry? of course, when the entry and the survey were not identical, title could be established only to the land included in both. Can we be surprised, with land so abundant, that many tracts seem to have been "mosurea with a coon skin with the tail thrown 
In?" Mistakes were multiplied when a survey full of errors was accopted in marking out adjacent grants. Distances incorrectly stated, water courses erroneous If shown caused overlapping of patents.

Virginia had granted land in her unmeasured wilderness with a free hand. Often four entries would cover the same ground." There were no banks in these early days and land warrants were used as currency, security and for investment. Companies in the Bast owned grants for vast acreage of western lands. When Kentucky applied for statehood, there was a rush to locate the warrants under the Virginia laws. The influence of these eastern men with western holdings probably played a prominent part in delaying Kentucky's admission to the union. Lit1gation over these old land titles persists even to this generation.

Kentucky's land pollcy was directed by a General Assembly which strove to help the individual settler become a land owner and an established citizen; and to protect the rights of the poor clalmant in his struggle to own land. Laws passed for acquiring title to land were intended to benefit the actual settler. Persons

* Ur. R. C. Ballard Thruston of Loulsville, Ky., says he, himseif, has found Virginia grants four deep on Eastern Kentucky lands. 
receiving a large grant were obliged ${ }^{(26)}$ to definitely understand and allow for the grant of the small settler in their tracts. The occupying claimant laws insisted that a person "peacefully seated on land which they have improved, supposing them his own ... (shall) be paid by the owner for improvements," if a prior claim to the land forced him to relinquish it. A settler was allowed to take up other vacant lands and to transfer ${ }^{(27)}$ all fees paid to the now holdings when it was proved he had taken up military land by mistake.

If the settler failed to secure the necessary money for land payments, extra time was given him. Many acts ${ }^{(28)}$ extended the time for making the survey and registering the survey of grants. Iand could be paid for over several years in annual installments. (29) The timo of payment was many times extended. Annually the sales of land for debt were postponed. (30) Head-right land struck off to the state for debts could be redeemed by paying the amount of the principal due with costs of sale and redemption. The state held this land for the original owner to redeom、

Land was not exposed ${ }^{(31)}$ for sale after the

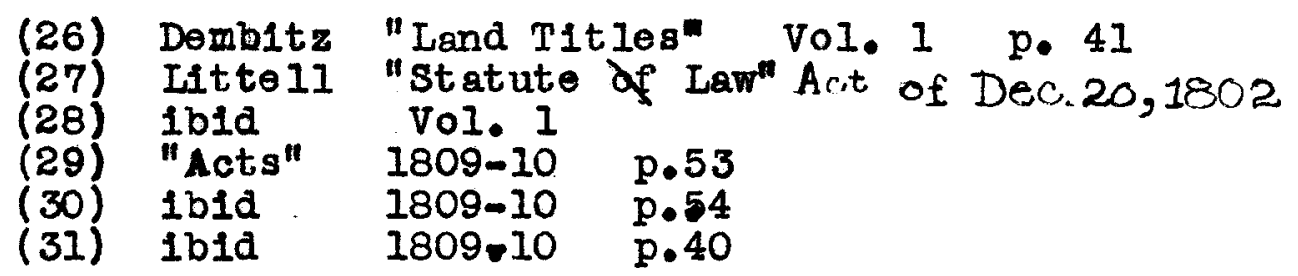


death of the taker-ip or assignee unt11 after the infant heirs were twenty-one years of age.

There were dishonest lawyers and land

speculators who took advantage of the ignorance and poverty of settlers. From these the state was powerless to give protection. False entries and dishonesty in survejs by state emplojees was penalized by law, but there were dishonest clerks and surveyors. Later laws were unable to entireig rectify the consequences of early mistakes and carelessness. But, on the whole the story of the disposal of her public land by the state of Kentucky is an honest and honorable one. 
92.

AFPSNDIX I 
This survey, the original of which is in the Daniel Boone Collection at the old state capital in Frankfort, Kentucky, is an old Virginia surveyor's certificate.

Feb. 10, 1784 .

Surveyed for Daniel Boone

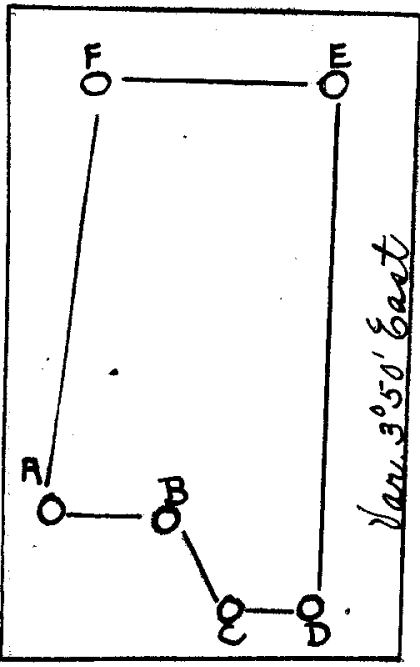

$\Delta p^{e \theta}$ of William Hayes $\Lambda p^{e \theta}$ of

Benjamin Winslow 500 acres of land

by virtue of a treasury warrant duly entered October the $2^{\mathrm{d}}, 1780$. No 223 Situate lying and being in the county of Fayette on Boon's Creek joyning and between the Lands of James H1ckman and Matis on (?) and bounded as Follows by Begining at A. T. Hickman's and a white oak being Matis on's S. E. corner, Thence Bast 92 Poles to (B) a white oak, thence $S 25^{\circ} \mathrm{E} 118$ Poles to (C) two cedars on Bogse's Fork, Thence East 88 Poles to (D) Two White 0aks and an Fim, Thence North 486 Poles to (B) Two Hickeries and a Red Oak in Hickman's line, Crossing Boon's Creok six times, Thence West 102 Poles to (F) a hickery in Matison's line crossing one fork of B creek Thence south $27^{\circ} \mathrm{W} 318$ Poles to $A$ the Begining. 


\section{Daniel Boone Dr (?)}

\section{Tellar J. Hall}

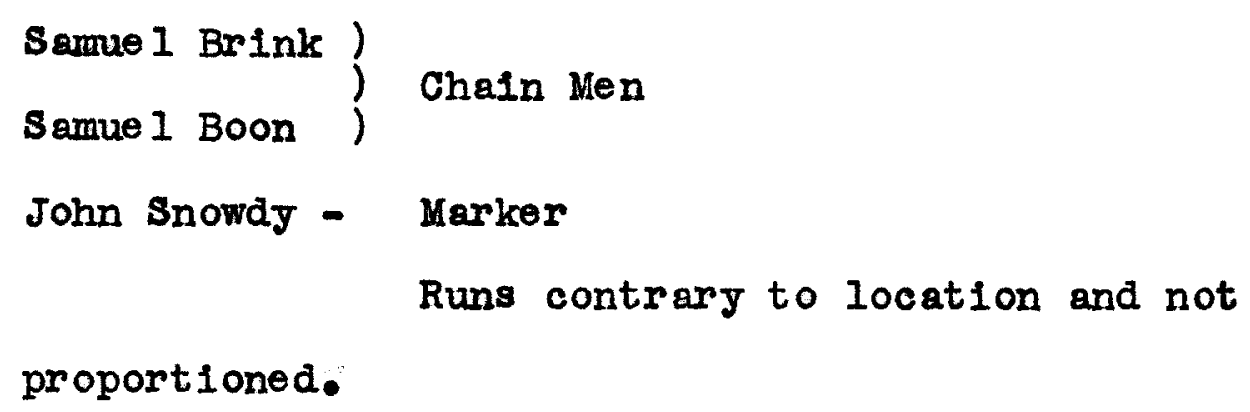


95.

APPENDIX II 
An interesting example of laying an old Virginia warrant on land is shown in this advertisement appearing in the December 14, 1810 issue of the "Argus of Western America" a newspaper published at Frankfort. "On the 8th day of January next, if fair, if not, on the next fair day, we shall attend with the commissioners appointed by the county court of Shelby, at the fork of the Frankfort andrennon's Ifick roads for the purpose of perpetuating testimony on the following entries (and continue from day to day until completed), to wit Dec. 24th, 1782 - Squire Boone enters 12335 acres on a T.W. No 12194 on the head waters of Drennon's Lick objects of notorlety to be established are - Drennon's Iick Creek - the Big Creek - the painted stone and Boone's 12335 acre tract."

John White

John McClelland 
APPENDIX III 
The commissioners regularly appointed to determine settlement and boundaries met where convenient. "Notice is hereby given to all whom it may concern that Compissioners appointed in conformity with an act of Assembly of the state of Kentucky entitled "An act to ascertain the boundaries of land and for other purposes" will meet on the land of Thomas Filliams on the big west fork of Lawrence's creek in the county of Mason etc." And again "I shall attend with commissioners appointed for the county court of Clark at a poplar tree marked J. H. on a branch of Lulbulgrad Creek etc."

Kentucky Gazette, Dec. 5, 1795. 
BIBIIOGRAPHY 


\section{GENRRAL WORKS}

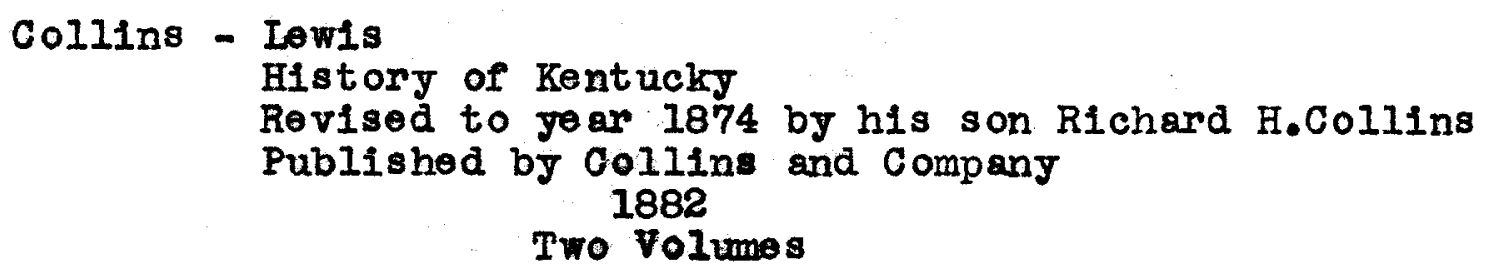

\section{SPECIAL WORKS}

Carroll - Kentucky Statutes

Containing All Laws of a General Nature in Force to January 1,1930

Official Bdition under the Fditorial

supervision of William Bdward Baldwin

The standard Printing Company

Louisvilie

Dembitz --

Land Titles

1895

Two Volumes

Henking - William Waller

Statutes at Large of the General Assembly

Richmond 1819-23

A Collection of all the Laws of Virginia Printed by George Cochran

Richmond 1822

Volumes 9 and 10 used 
Jills on - Willard Rouse The Kentucky Land Grants

Fils on Club Publication (1925)

Iittell - William

The Statute Law of Kentucky

With Notes, Praelections and Observations

on the Pubilic Acts

Published by Wm. Hunter 1809

Three Volumes

Volume Four added in 1814

Volume Five in 1819

Butler and Wood, Printers

Littell (W1iliam) and Swigert (Jacob)

Digest of the statute Law of Kentucky

Published under the Patronage of the Legialature

Published by Kendall and Russell 1822

Frankf ort

Malone - James H.

The Chickasaw Nation

A Short Sketch of a Noble People

Printed by John P. Morton Co. 1922

Iouisville

Powell - J. W.

Fifth Annual Report of the Bureau of Ethnology to the

Secretary of the Bmithsonian Institution 1883-84

Government Printing office 1887

Powe II - J. W.

Fighteenth Annual Report of the

Bureau of Ethnology to the

Secretary of the Smithsonian Institution 1896-97

Government Printing office 1899

(Wheaton) Condensed Report of the Cases in the Supreme Court of the United States - Volume V Bdited by Richard Peters

Published by DeSilver, Jun. and Thomas 1833

PhIladelphia 
Young - Bennett $\mathrm{H}$.

History and Texts of the Three

Constitutions of Kentucky

Courier-Journal Job Printing Company 1890

Louisville

\section{SOURCE MATERIAL}

American State Papers

Documents legislative and executive of the Congress of the United states

Fdited by Lowrie and Clark under authority of Congress, Washington, 1832

Volumes 7 and 8 "Indian Affairs"

History of Congress

Debates and Proceedings of the Fighteenth

Congress - First Session

Published by Gales and seaton

Washingt on

Journal of the Continental Congress

Edited from the original records in the

Iibrary of Congress by Worthington Chancery

Ford

Government Printing Office

$$
\text { 1904-22 }
$$

Acts of the General Assembly of the Commonwealth of Kentucky

(Various governors)

Published by Authority at Frankfort by the state

Printer at the close of each session

Journal of the House of Representatives of Kentucky for 1823

Printed by Jacob H. Holeman - Printer for the State 1823

Frankf ort

Journal of the senate of the Commonwealth of Kentucky (Journals of 1821 and 1826 used)

Printed by Printer for the State at

Frankfort at the close of the sessions 


\section{ORIGINAI SOURCES}

\section{Kentucky Gazette - A newspaper published at Iexington, Kentucky. Files in the Iexingt on Public Library. \\ Argus of Western America - A newspaper published in Frankfort. Some copies in the Historical Collection at Frankfort.}

Original Surveys and Entries in Historical Collection at Frankfort. 